\title{
Role of galectin-glycan circuits in reproduction: from healthy pregnancy to preterm birth (PTB)
}

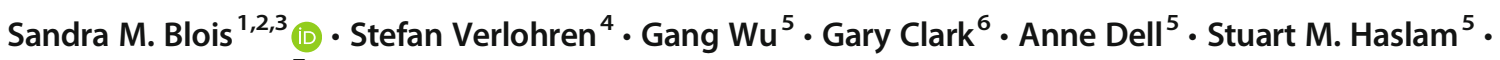 \\ Gabriela Barrientos ${ }^{7}$
}

Received: 24 March 2020 / Accepted: 20 May 2020 / Published online: 29 June 2020

(C) The Author(s) 2020

\begin{abstract}
Growing evidence suggests that galectins, an evolutionarily conserved family of glycan-binding proteins, fulfill key roles in pregnancy including blastocyst implantation, maternal-fetal immune tolerance, placental development, and maternal vascular expansion, thereby establishing a healthy environment for the growing fetus. In this review, we comprehensively present the function of galectins in shaping cellular circuits that characterize a healthy pregnancy. We describe the current understanding of galectins in term and preterm labor and discuss how the galectin-glycan circuits contribute to key immunological pathways sustaining maternal tolerance and preventing microbial infections. A deeper understanding of the glycoimmune pathways regulating early events in preterm birth could offer the broader translational potential for the treatment of this devastating syndrome.
\end{abstract}

Keywords Galectins $\cdot$ Preterm birth $\cdot$ Microbial infections $\cdot$ Glycans

\section{Introduction}

Galectins play a paramount role in pregnancy biology, modulating a wide range of processes from embryo implantation to parturition. Different galectins coexist at the feto-maternal interface where besides coordinating placentation and maternal immune adaptation to the semi-allogenic fetus, they also play a role in maternal vascular expansion [1]. Though most of their biological functions during gestation are exerted through

This article is a contribution to the special issue on Preterm birth: Pathogenesis and clinical consequences revisited - Guest Editors: Anke Diemert and Petra Arck

Sandra M. Blois

s.blois@uke.de

1 Experimental and Clinical Research Center, A Cooperation Between the Max Delbrück Center for Molecular Medicine in the Helmholtz Association and the Charité-Universitätsmedizin Berlin, AG GlycoImmunology, Berlin, Germany

2 Institute for Medical Immunology, Charité-Universitätsmedizin Berlin, Berlin, Germany

3 Department of Obstetrics and Fetal Medicine, University Medical Center Hamburg-Eppendorf, Hamburg, Germany binding endogenous glycan structures, galectins can also recognize exogenous specific glycans on the surface of bacteria, viruses, parasites and therefore function as pattern recognition receptors [2]. As a result, galectins appear to be critical in the microbial glycan-host interactions that promote the engagement of specific immune cell subsets and shape host immunity. Thus, given their unique ability to modulate maternal immunity galectins emerge as important players in preterm birth (PTB) syndrome, which most often is associated with
4 Department of Obstetrics, Charité-Universitätsmedizin Berlin, Berlin, Germany

5 Department of Life Sciences, Imperial College London, London, UK

6 Department of Obstetrics, Gynaecology and Women's Health, University of Missouri, Columbia, Missouri, USA

7 Laboratory of Experimental Medicine, Hospital Alemán, School of Medicine, University of Buenos Aires, CONICET, Buenos Aires, Argentina 
microbial infections that disrupt fetomaternal tolerance due to the drastic link between underlying pathogens and their ability to promote inflammatory responses $[3,4]$.

Host-pathogen interactions fundamentally shape a broad range of biological processes. While products of microbial metabolism can impact a wide variety of host activities, from neurological function to overall metabolism and immune homeostasis (1-3), direct interactions between host and microbes can fundamentally shape microbial flora, impact immune function and often ultimately dictate the likelihood of infectious disease (4). Although host factors can interact with a variety of distinct microbial molecular determinants, cell surface glycans represent the most unique, diverse, and rich molecular features that decorate microbes $(5,6)$. As microbial carbohydrate determinants often completely envelope microbes, these structures often represent the first and most significant molecular signature encountered by a host. As a result, hosts appear to have evolved a variety of immune factors that possess the ability to recognize the distinct carbohydrate signature of a broad range of microrganisms (6-9). Indeed, many immune populations are defined by the distinct repertoire of glycan-binding proteins (GBPs) they express (6-8), strongly suggesting that microbial glycan-host interactions may result in the engagement of specific immune cells and thus shape host immunity in fundamental ways.

\section{Galectins and the control of pregnancy-associated processes}

Galectins are small, soluble glycan-binding proteins characterized by their affinity to $\beta$-galactosides and the presence of an evolutionarily conserved sequence, the carbohydrate recognition domain (CRD), which mediates binding to their specific N-acetyllactosamine $[\mathrm{Gal} \beta(1-4)$-GlcNAc]-enriched ligands [5]. In mammals, 15 members of the galectin family have been identified so far, of which 13 are expressed in humans [6]. Based on their molecular structure, they are classified into three main types: prototype, chimera, and tandemrepeat galectins (Fig. 1). While some of these galectins contain one CRD and are biologically active as monomers (i.e., gal-1, gal-13) or as oligomers that aggregate though their non-lectin domain (gal-3); others contain two CRDs connected by a short linker peptide (e.g., gal-9). Galectins are synthesized in the cytoplasm, where they exert intracellular functions modulating various processes including cell growth, differentiation, survival, and migration [7]. In addition, some galectins can translocate to the nucleus and participate in transcriptional regulation and mRNA splicing [7,8]. However, galectins can also be present on the cell surface or secreted to the extracellular compartment [9], where they engage in protein-glycan interactions with cell surface or ECM molecules and regulate a diverse combination of biological functions such as cell adhesion, apoptosis, lattice formation, and invasion [10-13].
With their various functions, galectins link innate and adaptive immune responses acting as key regulators of acute and chronic inflammation, host-pathogen interactions, and immune tolerance, which all are implicated in a healthy pregnancy [14-18].

\section{Embryo implantation}

It is now firmly established that the role played by galectins during the establishment and maintenance of gestation is attributable to the several pathways these endogenous lectins coordinate. Figure 1 illustrates the galectin-associated mechanisms during a healthy gestation. Evidence from in vitro and expression studies suggest galectins are important mediators in the implantation process. Indeed, during embryo implantation the increased expression of gal-1, -3 , and -9 in endometrial epithelial cells suggest their role in uterine receptivity [19-22]. In support of this, the ability of galectins to bind laminin and fibronectin [23] may serve as a link between endometrial epithelial cells and the blastocyst. Human embryos express gal-1 at early stages of development (day 3-day 5) in their trophectoderm and secrete gal-1 into the medium in which they are cultured [24], suggesting that this lectin may influence uterine blastocyst attachment during the window of implantation. In this regard, Jeschke's group has shown that gal-1 binds mucin-1 (MUC1) via the Thomsen-Friedenreich (TF) epitope on glandular epithelial cells and endometrial epithelial apical surface tissue [25], implying that embryonicderived gal-1 may bind to endometrial MUC1 via the TF epitope during implantation. Interestingly, integrins (e.g., $\alpha \beta 3$ ) have been proposed to have important roles during implantation [26] and the integrin $\beta 3$, which is highly expressed in the luminal and glandular epithelium, could also serve as a ligand of gal-1 and gal-3 to promote trophectoderm-uterine epithelium interactions [27]. Thus, galectins (especially gal1 , gal-3, and gal-9) participate not only in the uterine epithelial preparation for receptivity but also in blastocyst activation influencing the embryo-derived signals for implantation.

\section{Maternal Tolerance}

The establishment and maintenance of pregnancy represent a major immunological challenge requiring a delicate balance of inflammation and immune tolerance at the fetal-maternal interface. During early stages, proper implantation and uterine vascular adaptation are characterized by an inflammatory milieu, which later must be switched to a down-modulation of the immune response allowing tolerance of the semi-allogenic fetus. Later on, a new switch to inflammation is required in the last stage to ensure the activation of labor. This key immune switching mechanism at the fetal-maternal interface relies on a highly orchestrated crosstalk involving the placental trophoblasts and different maternal immune cell subsets, such as 


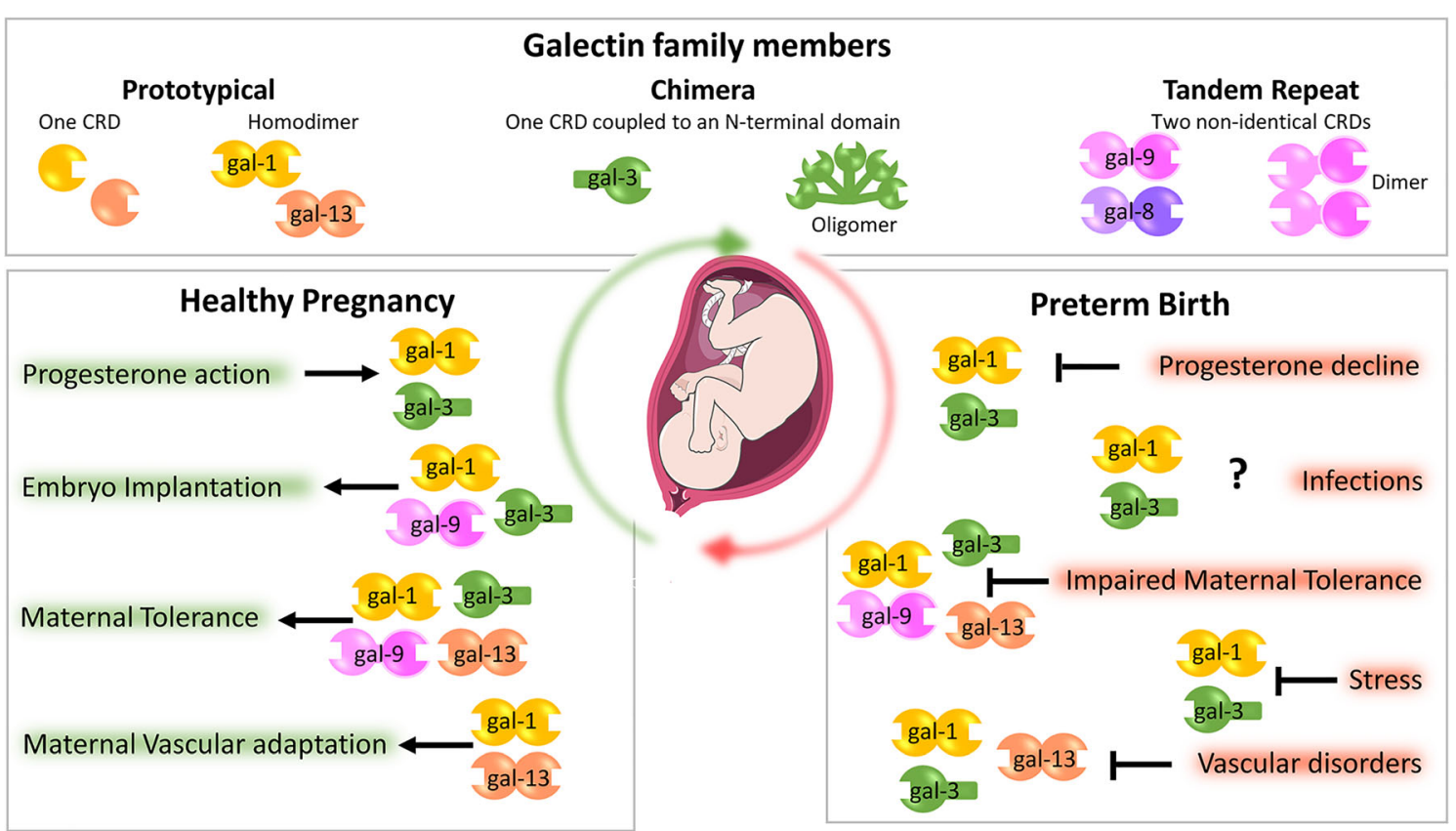

Fig. 1 Biological function of galectins at the feto-maternal interface. The galectin family members are divided into three types: the prototype with one carbohydrate recognition domain (CRD), the chimeric type with one $\mathrm{CRD}$ and a non-lectin $\mathrm{N}$-terminal domain and the tandem -repeat type with two CRDs connected by a non-conserved linker. Some galectins can self-associate into dimers or oligomers. Under normal conditions, individual galectins promote healthy gestation regulating placentation,

regulatory macrophages, natural killer (NK) cells, and T cells (recently reviewed in [28]). Thus, maternal immune adaptation to pregnancy is a highly regulated process involving several galectins [6, 15, 29-31]. In this regard, pioneering studies by Than NG et al. have shown that placenta-specific galectins (e.g., gal-13, -14 and -16), predominantly expressed by the syncytiotrophoblast cells, induce maternal $\mathrm{T}$ lymphocyte apoptosis [32]. In a more recent work, Than's group showed that gal-13 and gal-14 have a basic pro-apoptotic activity on $\mathrm{T}$ cells regardless of their activation status [33]. However, cytotoxic T lymphocytes were more susceptible to gal-13/gal-14 induced apoptosis than $\mathrm{T}$ helper cells, probably due to the differential glycosylation pattern on these two $\mathrm{T}$ cell populations [34]. In addition, gal-1 is highly expressed in the hemochorial placenta, where it has been shown to modulate human leukocyte antigen G (HLA-G) expression on extravillous trophoblast (EVT) cells, thereby promoting one of the chief mechanisms of immune tolerance operating at the human maternal-fetal interface [24]. The immune regulatory effects of HLA-G include impacts on NK cell killing activity, suppression of cytotoxic $\mathrm{T}$ lymphocyte killing activity and viability, inhibition of proliferation and induction of a suppressive phenotype in Thelper cells, and alteration of dendritic cell maturation and stimulatory capacity (reviewed in [35]). The expression of gal-9 by human trophoblast has been shown to promote the development of uNK cells with a tolerogenic maternal immune and vascular adaptation to pregnancy. Progesterone induces the expression of galectin-1 (gal-1) and gal-3 during embryo uterine receptivity. Factors implicated in the development of preterm birth are likely to contribute locally to galectin dysregulation and as a consequence breakdown of maternal immune tolerance and vascular disorders may trigger spontaneous preterm labor

phenotype via Tim-3 engagement [36], which is supported by data indicating that the Tim-3/gal-9 pathway downregulates Th1 immunity [37]. Additionally, galectins are also expressed by maternal immune cells, which infiltrate the decidua. For example, gal-1, secreted by uterine natural killer (uNK) cells, induces the apoptosis of activated decidual $\mathrm{T}$ cells with a glycophenotype compatible with this lectin [38]. uNK cells also selectively express type $2 \beta-1,6-N$-acetylglucosaminyl transferase (C2GNT), the glycosylation enzyme required to initiate the formation of gal-1 specific ligands, implying an autocrine role of this lectin in down-modulating the cytotoxic potential of uNK cells [38]. Gal-9 has an immunosuppressive activity similar to gal-1 at the maternal side [39]. The effect of Lgals9 D5 (the predominant gal-9 splice variant) was tested on uNK cells in mice and it was found to downregulate IFNgamma production through carbohydrate dependent interaction [39]. Thus, gal-9 could participate in the limitation of Th1 and shift to a protective $\mathrm{Th} 2 \mathrm{milieu}$, which is further supported by the impaired decidual expression of gal-9 in mice and human pregnancy complicated with spontaneous abortion induced by $\mathrm{T}$ helper cytokine imbalances [39]. The ability of gal-1 to maintain the balance between pro-inflammatory Th1/ Th17 and Th2 cytokines needed for healthy gestation is critical. We have shown that gal-1 promotes the expansion of IL10 producing regulatory $\mathrm{T}$ cells [15]. In line with these findings, LGALS1 null mice display exacerbated Th1/Th17 
responses and a higher frequency of immunogenic DC [34, 40] and show increased fetal loss rates in allogeneic pregnancies with susceptibility to stress-induced abortions $[15,41]$. In summary, these evidences support a role for galectins in dampening inflammatory responses and promoting tolerogenic cell phenotypes specifically at the fetal-maternal interface. During pregnancy, this serves as a mechanism of promoting maternal tolerance to the fetus through preventing deleterious anti-fetal $\mathrm{T}$ cell responses.

\section{Maternal vascular adaptations for placental development}

A proper placental development requires a deep maternal vascular adaptation in early gestation. In this regard, different steps of the angiogenic cascades and endothelial cell biology are influenced by galectins (e.g., gal-1, gal-3, gal-8, gal-9) [42]. For instance, several lines of evidence demonstrate proangiogenic functions for gal-1, which result from direct effects on endothelial cell activation via H-Ras signaling [43] as well as from the modulation of endothelial cell adhesion, migration and proliferation by interacting with the neuropilin (NRP)-1/VEGFR2 signaling pathway [44]. Murine studies have demonstrated a critical role of VEGFR2 signaling during the physiological adaptation of the maternal vascular bed to embryo implantation [45], which together with the high local expression of NRP-1 during peri-implantation stages [46] points out to a paramount role played by this lectin in the control of pregnancy angiogenic responses. Indeed, treatment with anginex (an artificial $\beta$-peptide targeting gal1 proangiogenic functions) resulted in decreased adhesion and capillary tube formation in SGHPL-4 EVT-like cells in vitro and impaired spiral artery remodeling and placental function in an in vivo mouse model, causing preeclampsia-like symptoms during late gestation and fetal growth restriction [47].

Another galectin likely to be involved in maternal vascular adaptation is gal-13 (placental protein 13, PP13), though evidence in support of its role per se in the modulation of angiogenic pathways is still elusive. In decidual tissue, gal-13 is found selectively associated with T-cell-, neutrophil-, and macrophage-rich foci of necrosis [48], suggesting that it might act to attract, activate and kill maternal immune cells facilitating trophoblast invasion and spiral artery remodeling. More recently, in vivo studies demonstrated hypotensive effects in pregnant rats infused with gal-13 [49], associated with increased heart rate and decreased peripheral resistance due to general vasodilation. It was later demonstrated that gal-13 infusion both during pregnancy and in the non-pregnant state was associated with vasodilation of veins and resistance arteries beyond the uterine vascular tree [50,51], suggesting that placenta-derived gal-13 may be involved in generating a systemic endothelial effect in the mother mediated by endothelial nitric oxide synthase (eNOS) and prostaglandin signaling.

\section{Galectins in parturition}

Parturition is a coordinated process referred to as the "common pathway" that involves increased myometrial contractibility, cervical ripening, activation of the decidua, and fetal membranes with local pro-inflammatory changes. These processes involve different uterine compartments including the decidua, myometrium, fetal membranes, and placenta implying that activation of biological pathways may be different across the various gestational tissues. As galectins are widely expressed, we intend to discuss the galectin signature of gestational tissues at term taking into consideration the origin of the expression. However, due to the intimal interaction between decidua, chorion, and amnion, it may be difficult to infer the galectin expression pattern of these tissues separately. Although data is relatively scarce, evidence suggests that at term, gal-1 is the galectin with the highest expression in the human decidua. In healthy laboring women, gal-1 and gal-3 expression levels within the decidua decreased when compared to non-laboring women [52]. Consistent with this, maternal gal-9 circulating levels are elevated early in healthy pregnancy and remain increased until parturition, returning to non-pregnant levels in the post-partum period [53]. In pregnant mice, gal-3 is mainly expressed in the endometrial cells of the primary decidua basalis, metrial gland, and placenta; and after parturition this lectin expression decreased as the implantations sites resorbed [54], implying that the parturition process at least in humans and mice occurs with a dysregulation of the glycan-binding proteins.

\section{PTB, a complex syndrome associated with multiple causes}

PTB is defined as birth before $37+0$ gestation weeks (GW). However, the simplicity of the definitions is in sharp contrast to the complexity of the disease, whose etiology is far from being understood. PTB is the leading cause of neonatal morbidity and mortality and the single major cause of death in children up to 5 years of age in the developed world [55]. About 15 million preterm neonates are born each year where genetic variation in human birth timing imposed a high risk for prematurity in the African American population [56]. In the European Union, the PTB rate has risen constantly over the last 10 years, a trend which corresponds to global figures $[57,58]$. The prevalence varies from country to country with a median of $7.1 \%$ of all births. In Germany, $9 \%$ of all children were born before the end of GW 37 . In parallel, the rate of extremely preterm deliveries $(<28 \mathrm{GW})$ has risen by $64 \%$. Neonates that are born preterm are at an increased risk of short-term and long-term complications, with the former being attributed to the immaturity of multiple organ systems and the later ranging from disabilities originating from these early complications to subtle neurodevelopmental impairment [59] (Fig. 2). 


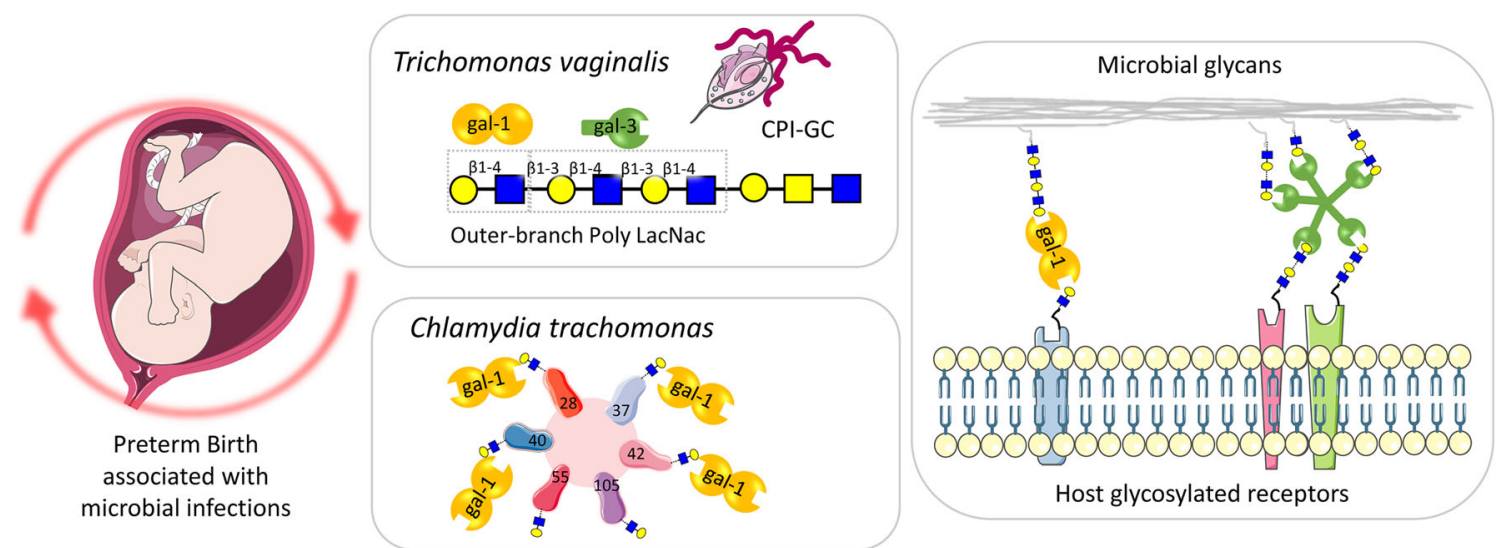

Fig. 2 Microbial-induced inflammation and galectin-glycan circuits. Schematic diagram to illustrate galectin functions as pattern-recognition receptor for microbes associated with preterm labor. Galectin-1 (gal-1) and gal-3 specifically bind the N-glycans displayed in the Lipophosphoglycan (LPG). Gal-1 is able to bind at least six chlamydia

Although preterm labor has a complex, multifactorial etiology [60] microarray data from uterine tissue revealed similar gene regulation patterns between term and preterm women suggesting that acceleration of the gestational clock appears to be involved in the PTB cases. In particular, spontaneous preterm labor is perceived as pathological activation of the above mentioned "common pathway" of parturition. Other key factors for labor, cervical ripening, and decidual/ membrane activation, involve specific changes in inflammatory and extracellular matrix proteins. These include increased expression of inflammatory cytokines e.g. tumor necrosis factor- $\alpha$ (TNF- $\alpha)$ and IL-1 and chemokines, increased activity of proteases matrix metalloprotease 8 (MMP-8) and MMP9, degradation of extracellular matrix components such as fibronectin and an increase in glycosaminoglycans and hyaluronan [61]. In addition, pro-inflammatory pathways including chemokines (interleukin-8 (IL-8)), cytokines (IL-1 and -6), and contraction-associated proteins (oxytocin receptor, connexin 43 , prostaglandin receptors) eventually contribute also to myometrial activation [62].

While many studies examined the roles of galectin interactions during gestation, the potential outcome of these interactions in the context of PTB remains elusive. Shankar and coworkers [63] have identified differences in choriodecidual gal1 expression between spontaneous preterm labor and gestational-matched non-laboring patients, suggesting that decreased levels of gal-1 are associated with the underlying pathology. Early studies demonstrated that galectins are expressed in cervical and vaginal epithelial cells [64], which could uniquely poise to engage microbes and initiate innate immunity. Indeed, the observation that gal-1 is able to downregulate the pro-inflammatory environment stimulated by LPS (e.g., IL-6 production, an important cytokine related to PTB) in decidual cells derived from elective cesarean patients at term suggests that this lectin may be important in the trichomonas glycoproteins (gp28, gp37, gp40, gp42, gp55, and gp105). Galectins may facilitate the ascendant infection during pregnancy by cross-linking host and microbial glycans. Abbreviations: Ceramide phosphoinositol glycan core (CPI-GC); gp glycoprotein

regulation of local inflammation during the course of chorioamnionitis [65]. Similarly, it has been shown that gal3 is increased in fetal membranes and in the amniotic epithelium in patients with chorioamniotic infection [66], thereby regulating the inflammatory response and/ or direct interaction with the pathogens. In the following sections, we discuss several of the multiple pathological processes associated with preterm labor and the relevance of galectin-induced immune-regulatory pathways:

\section{Decline in progesterone and anti-inflammatory mediators}

Progesterone is a key player in maintaining uterine quiescence, and a withdrawal of this hormone is observed at parturition onset. An understanding of this phenomenon has led to the successful application of progesterone in threatened preterm labor [67]. Moreover, a recent study has shown that progesterone treatment could serve as an anti-inflammatory strategy to prevent PTB and adverse neonatal outcomes induced by $\mathrm{T}$ cell activation [68]. While current data suggest that progesterone regulates endometrial galectin expression including gal-1 and gal-3 [69] and alterations of the progesterone receptor function during gestation associate with reduced levels of gal-1 expression [15, 70], future studies will likely determine whether alterations in galectin expression directly contribute to PTB pathophysiology.

\section{Microbial infection}

Microorganism-induced PTB is mediated by an inflammatory process and the most studied mechanism is the activation of toll-like receptors (TLRs). TLRs are membrane-bound proteins that recognize pathogen-associated molecular patterns (PAMPs) and activate the innate immune system to generate 
downstream signals through the release of cytokines (IL-1 $\beta$, TNF- $\alpha$ ), chemokines (IL-8, CCL-2), prostaglandins and proteases [71]. The activation of the innate immune response through TLRs has the aim to control microorganisms that may injure the embryo, however, excessive inflammation could eventually trigger the common pathway of parturition with cervical ripening, rupture of fetal membranes and placental detachment $[61,72]$. TLRs can be expressed in the cell surface (TLR-1, -2, -4, and -5) or in intracellular vesicles (TLR-3, -7, -8, and -9). Cell-surface TLRs recognize accessible PAMPs such as bacterial lipoproteins and lipoteichoic acid (TLR-2 as heterodimers with TLR-1 or TLR-6), lipopolysaccharide (LPS) of Gram-negative bacteria (TLR-4) or bacterial flagellin (TLR-5). Cytoplasmic TLRs recognize doublestranded RNA (dsRNA) (TLR-3), single-stranded RNA (ssRNA) (TLR-7 and TLR-8) or $\mathrm{CpG}$ enriched doublestranded DNA (TLR-9) [71].

In human pregnancies, TLR-1 to TLR-10 have been found and are mainly expressed by trophoblast cells, but also in the cervix and uterus [73, 74]. However, differential expression of TLRs has been observed according to the gestational age. Particularly, in the third-trimester placenta, the expression of TLR-2 was observed in endothelial cells, macrophages, and syncytiotrophoblast and TLR-4 was prominently expressed in syncytiotrophoblast and endothelial cells [75]. Functional analysis also demonstrated that the term placenta can respond to TLR-3, TLR-5, and TLR-7/8 agonists [76]. In a mouse model, it has been demonstrated that activation of TLR-3 with poly(I:C), an analog of dsRNA, promotes NF-kappa B signaling with the induction of pro-inflammatory cytokines and chemokines (e.g., IL- 6 , IL- $1 \beta$, TNF- $\alpha$, IFN- $\gamma$, IL- 8 , MCP1 ), leading to preterm delivery [77]. Moreover, in women with chorioamnionitis TLR-2 and TLR-4 are upregulated in fetal membranes [78]. Administration of peptidoglycan, which is part of the bacterial cell wall, induced TLR-1 and TLR-2mediated trophoblast cell death in vivo and in vitro. However, apoptosis could be inhibited by the presence of TLR-6, which also activates NF-kappa B signaling in trophoblasts with the secretion of IL-6 and IL-8 promoting an inflammatory response [79]. Both the pro-inflammatory response and trophoblast apoptosis are processes strongly implicated in PTB. As TLR-4 recognizes LPS it is not surprising that TLR4-deficient mice are not susceptible to LPS- or Escherichia coli-induced PTB [80, 81] and neutralizing antibody against TLR-4 can reduce inflammation-induced PTB and fetal death in mice [82]. In rhesus monkeys, pretreatment with a TLR-4 antagonist inhibited LPS-induced uterine contractility and reduced IL-8, TNF- $\alpha$, and prostaglandins [83]. Treatment with IL-10 prevented LPS-induced PTB with a reduction of TNF- $\alpha$, IL- 6 , and IL- $1 \beta$ in mice and rats $[84,85]$.

From the clinical point of view, associations between microbial induced inflammation and preterm labor have been reported in several studies [86-88], but it is not clear why some women experience PTB and some not, even with the same exposure to pathogens. A striking example is a discrepancy between the rate of lower genital tract and ascending intra-amniotic infections, implicating that the role of the maternal immune system is key to identify those at risk. Nevertheless, in $25 \%$ of all PTBs intra-amniotic infection is involved [89]. Ascending infections are the likely cause, as pathogens detected in the amniotic fluid and in the lower genital tract are the same [90]. Recently, the PREMEVA trial investigated the effect of screening and therapy for bacterial vaginosis (imbalance of naturally occurring bacterial flora with an increase of the anaerobic type) in pregnant women with a low or high risk of preterm labor (according to previous PTB history) treated or not with clindamycin, which is one of the two most often-used antibiotics to treat bacterial vaginosis during pregnancy. The authors concluded that bacterial vaginosis treatment in women with low-risk pregnancies did not show a reduction of spontaneous PTB suggesting that the use of antibiotics to prevent preterm delivery should be reconsidered [91]. This finding is in line with other previous randomized controlled trials and meta-analyses that have shown no effect of antibiotics for pregnancy prolongation in asymptomatic pregnant women with bacterial vaginosis [92-94]. In addition, recent studies report that positive diagnosis with Chlamydia trachomatis (the most common aerobic intracellular bacterium responsible for sexually transmitted infections) shows no significant association with spontaneous preterm labor [95]. However, other trials have shown that women with chlamydia infections are 2.28 more likely to deliver pre-term in comparison with those who were not infected [96]. Group B Streptococcus (GBS, a gram-positive bacterium) colonization is recognized as a risk factor for PTB as being the most frequent cause of severe early-onset infection in newborn babies. A recent review showed a consistent increase in the risk of PTB in women with maternal GBS colonization, which is stronger in case-control studies compared to cohort or cross-sectional studies [97]. For Trichomonas vaginalis, a vaginotropic extracellular protozoan parasite, similar results have been retrieved. Women with asymptomatic trichomoniasis were randomly treated with metronidazole or placebo. Preterm delivery occurred in 19\% of the metronidazole vs $10.7 \%$ in the placebo group. While metronidazole eliminated the organism, it was reported as ineffective in preventing preterm delivery and potentially even increasing it, which has led to early termination of the trial [98].

In the context of microbe recognition, galectins can directly engage microbes by binding specific glycans on their surface and thereby dictate the consequence of microbial exposure [99]. Thus, galectins can function as both pattern recognition receptors (PRRs) and innate immune effectors during microbial infections [100], promoting pathogen clearance through different mechanisms (i.e., phagocytosis, encapsulation, 
autophagy) or inhibiting adhesion and/or entry into the host cell. This recognition and effector role can however be 'subverted' by certain pathogens, which can take advantage of the host galectin repertoire for successful attachment, invasion, and immune evasion $[100,101]$. An example of this strategy relevant for PTB is the Trichomonas vaginalis lipophosphoglycan (LPG) and its immunocompetent ceramide phosphoinositol glycan core (CPI-GC) domaincontaining $\beta$-galactosides and abundant poly- $\mathrm{N}$-acetyllactosamine repeats [102], which provide targets for gal-1 and gal-3 recognition [64]. Recent studies in this area of research have demonstrated that gal-1 mediates the adherence of the parasite to cervical epithelial cells in an LPG-dependent manner [103]. Moreover, CPI-GC collected from multiple clinical isolates showed similar affinity to gal-1, but the affinity to gal-3 differed between isolates from different patients, suggesting that galectin-binding diversity may responsible for the Trichomonas symptom disparity [64]. Another valid example of preterm labor infection is Chlamydia trachomatis, with gal-1 being able to bind to at least six chlamydial glycoproteins (gp28, gp37, gp40, gp42, gp55, and gp105). Thus, gal-1 facilitates $C$. trachomatis infection by bridging bacterial and host glycosylated receptors (such as PDGFR $\beta$ and $\beta_{1} /$ $\alpha_{V} \beta_{3}$ integrins) [104]. As intrauterine ascension of pathogens through the vaginal tract is one of the routes of pathogenic entry that triggers preterm labor, all aspects regarding recognition properties of the female tract (vagina, cervix, and placenta) galectin repertoire and the dynamic of their subcellular compartmentalization/secretion and interactions with microbial carbohydrates warrant further investigations.

Evidence indicates a possible association between galectins and TLRs. A well-studied example in the context of infectioninduced PTB is group B streptococci, bacteria that produce membrane vesicles with extracellular matrix-degrading proteases and pore-forming toxins leading to collagen degradation in the chorio-decidual membranes [105]. Interestingly, in vitro stimulation of cord blood samples with an invasive strain of Streptococcus agalactiae (a group B Streptococcus) induces gal-3 expression. Since fetal gal-3 serum levels increase with gestational age, the authors speculated that impaired gal-3 expression may contribute in part to the high susceptibility of preterm infants to infection as opposed to term infants or adults [106]. In addition, RNA interference against TLR-3 was shown to prevent gal-9 expression in human umbilical vein endothelial cells (HUVECs) stimulated with poly(I:C) [107]. In line with this finding, activation of TLR-3 (by poly(I:C)) and TLR-4 (by LPS) on fibroblasts derived from rheumatoid arthritis patients lead to apoptosis protection through induction of gal-9 expression [108]. Moreover, gal9 was increased upon stimulation with poly(I:C) in hepatitis C virus-infected monocytes [109]. With these evidences, we could hypothesize that activation of TLR-3 (principally by dsRNA produced by the virus) could increase gal-9 exerting a pro-inflammatory effect. It has also been described that gal-3 knockdown human synovial fibroblasts stimulated with an agonist to TLR-2 (Pam3CSK4), TLR-3 (poly(I:C)-), or TLR-4 (LPS) display a reduced response to TLR-mediated IL-6 secretion, suggesting gal-3 functions as a positive regulator of TLR activation [110].

Some evidence indicates a possible association between periodontal infection caused by oral pathogenic bacteria (e.g., Campylobacter rectus (C. rectus) or Porphyromonas gingivalis (P. gingivalis)) and PTB [111]. Enhanced placental TLR-4 expression was observed after oral infection with $C$. rectus and $P$. gingivalis [112]. In a mouse model with $P$. gingivalis infection, TLR-2-induced inflammation in the fetal membrane (activation of NF-kappaB and p38 MAPK pathways) leads to the upregulation of uterine contractility causing preterm delivery [113]. Similarly, $P$. gingivalis LPS induced IL- 6 and IL- 8 production via TLR- 2 in human chorion-derived cells [114]. Interestingly, increased gal-3 was found in the placenta, amniotic fluid, and serum in a PTB model of $P$. gingivalis-infected mice. In vitro culture of HTR-8/SVneo trophoblast cells with $P$. gingivalis LPS, demonstrated increased levels of TNF- $\alpha$ and gal-3, and gal3 inhibition significantly downregulated $P$. gingivalis LPSinduced TNF- $\alpha$ production [115]. During the neuroinflammatory response, it was demonstrated that gal-3 associates with TLR-4 through its CRD [116]. Moreover, $P$. gingivalis LPS increased gal-9 expression in the human periodontal ligament (connective tissue fibers) [117] suggesting a role for gal-9 during infection-induced PTB.

We have demonstrated that stress challenge during early pregnancy can enhance permeability of mucosal membranes to the entry of bacterial products (e.g., LPS) and promote transmucosal migration of commensal bacteria inducing fetal loss in mice [41]. Stress-triggered fetal loss was prevented by blocking of TLR-4 (anti-TLR-4 antibody) or neutralization of LPS (using the bactericidal/permeability-increasing protein (BPI), a protein that specifically binds and neutralizes LPS). In addition, gal-1 deficient female mice were highly prone to stress-triggered complete implantation failure, but treatment with BPI markedly reduced the detrimental effect of stress in pregnancy outcomes. However, there are not data available regarding the susceptibility to ascending infections and PTB in gal-1 deficient mice. The anticipated role of gal-1 as a key factor against pathogen mediated PTB suggests that insufficient gal-1 could be a critical factor that predisposes some women to infection-mediated PTB.

\section{Clinical management}

Screening for PTB consists in determining risk factors by taking a detailed history of the pregnant woman. Ideally, potential risk factors such as status post $(\mathrm{s} / \mathrm{p})$ previous PTB, short interpregnancy interval et al are determined before pregnancy 
allowing for preventive strategies. General primary prevention includes cessation of smoking and treatment of bacterial vaginosis in pregnancy [118]. However, in women with a history of PTB, the prophylactic treatment with vaginal progesterone or even a prophylactic cerclage may be considered [119]. General screening for PTB such as routine measurement of the uterine cervix by transvaginal sonography is not recommended. However, sonographic assessment of the cervical length should be included in the diagnostic work-up in symptomatic pregnant women (regular spontaneous preterm contractions) and/or in women with risk factors for spontaneous PTB [120]. In addition to transvaginal sonography, biomarkers such as PAMG-1, fetal fibronectin, and phIGFBP-1 obtained from cervico-vaginal secretions may be used to specify the risk of a PTB within the next seven days [121]. In women with a sonographic short cervix, secondary prevention consists of treatment with vaginal progesterone [122]. Treatment with a cervical pessary has not demonstrated to decrease the rate of spontaneous early preterm delivery [123]. Before 24 weeks, cervical cerclage may be the treatment of choice [124]. It should be noted that these measures have only proven to be effective in singletons and not in multifetal gestations.

The main aim of tertiary prevention in the context of threatened PTB before 34 weeks of gestation is to prolong pregnancy for at least $48 \mathrm{~h}$ in order to allow for the antenatal corticoid application. There is broad international consensus that placenta-crossing steroids (betamethasone, dexamethasone) must be given to women at imminent risk for PTB before 34 weeks in order to accelerate organ maturation of the fetus [125]. In order to achieve that, tocolysis, emergency cerclage, progesterone, and vaginal pessary can be used, adapted to the clinical situation and after counseling, ideally involving a multidisciplinary team including a neonatologist. Accurate assessment of the remaining pregnancy duration is paramount in order to find the best timing of steroid application as the ideal window is seven days before birth. Preterm premature rupture of membranes (PPROM) requires balancing the risks between prolongation of pregnancy for maturation and timely delivery in order to prevent the potentially devastating complications of ascending intrauterine infections.

In our view, management of threatened PTB is largely symptom-driven and preventative and the therapeutic strategies are guided not by causative approaches, but rather by preventative measures. Research in the field of PTB must be intensified in order to clarify the underlying etiologies allowing for targeted strategies in the future. Insights into the galectin-glycan circuits of tissues such as myometrial smooth muscle cells, decidua, placenta, amnion as well as fetal and maternal blood are sparse [62]. Identifying specific glycoimmune phenotypes, as well as factors capable of modulating maternal immune responses, can help to better predict which women might be at risk for preterm labor, permitting better surveillance and prophylaxis.

\section{Galectin-glycan circuits as modulators of inflammation and infection: insights from pregnancy}

Glycans are essential functional groups that facilitate and influence the reproduction process. For instance, the embryo implantation process is driven by glyco-specific interactions between the uterine epithelium and the outer trophoblast cell layer of the blastocyst, such that perturbations of the system generally result in implantation failure or poor pregnancy outcomes. Glycosylation relies on a delicate balance in the activity of specific modification enzymes (glycosyltransferases and glycosidases), and the glycocode expressed in a particular tissue is highly dependent on the cell type and its developmental, nutritional and pathological state. The specific glycome expressed at the maternal-fetal interface can play multiple roles during pregnancy. For example, N-linked glycans (attached to the nitrogen of an asparagine side-chain) have been shown to modulate trophoblast invasion [126, 127] and maternal-fetal tolerance [128, 129] during placentation. O-Linked glycans (attached to the hydroxyl oxygen of serine, threonine, tyrosine, hydroxylysine, or hydroxyproline side-chains) can influence recognition events during fertilization (e.g., sperm-egg interactions) [130].

Extracellular functions of galectins depend on the crosslinking of surface $\mathrm{N}$ - and O-glycans expressed by maternal immune cells, trophoblasts, and endothelial cells at the fetalmaternal interface (Fig. 3). As glycosylation is directly related to the physiological cellular status, changes in glycan composition are highly regulated during pregnancy and can have a fundamental impact on galectin activity [131-133]. For instance, placental expression of $\mathrm{N}$-acetylglucosaminyl transferase $\mathrm{V}(\mathrm{GnTV})$, which generates the $\beta 1-6-\mathrm{N}$-acetylglucosamine branches in complex $\mathrm{N}$-glycans recognized by gal-1, is enhanced in the first trimester compared with term pregnancies [126]. Since gal-1 promotes EVT differentiation and invasion during early pregnancy [134], it is possible that increased activity of GnTV may lead to enhanced signaling by this lectin [127]; particularly by promoting its interaction with cell surface $\beta 1$ integrin [127, 135-141] Furthermore, villous tissues from early spontaneous miscarriages show a reduced abundance of such $(\beta-6)$ branches together with decreased GnTV expression in comparison with healthy pregnancy villous tissues [142]. Thus, differences in the glycan composition of trophoblast related-proteins at the same gestational age could be important disease biomarkers that await further investigation. Indeed, the placental expression of GnTV was reported to be elevated in preeclampsia compared to normal pregnancies [143]. Thus, increased gal-1 expression as we have demonstrated in late-onset preeclampsia could represent a protective mechanism of the trophoblast to overcome the severe inflammatory milieu that characterizes the syndrome [47]. This is an interesting example of how the metabolic status of trophoblast cells is reflected by their glycan signature, which is shaped by the intracellular 


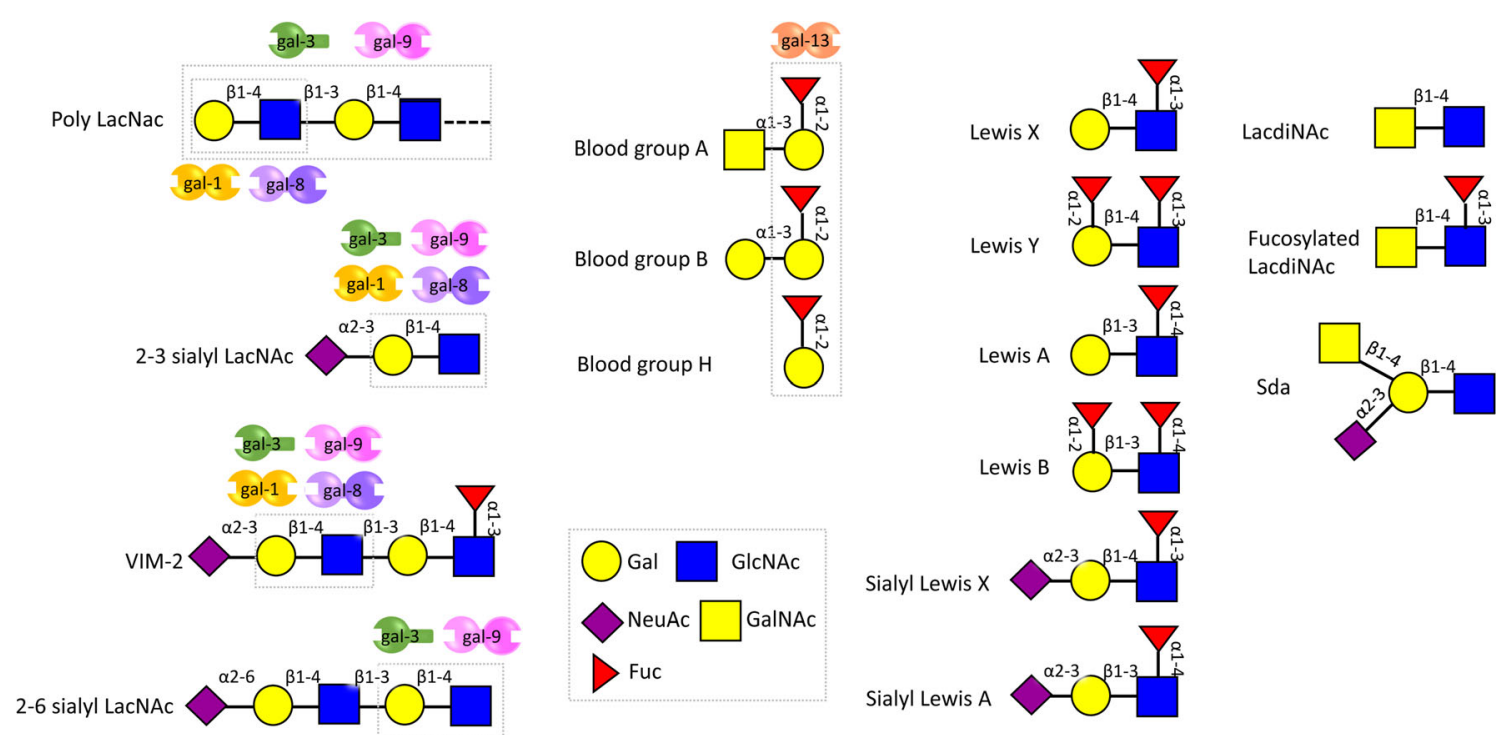

Fig. 3 Glycan terminal structures found in the reproductive system. The LacNac structures can be potential ligands for galectins expressed in the reproductive system, and the binding epitopes are shown within rectangles. Modifications of LacNac structures by sialic acid and fucose

levels of GnTV expression affecting the quality and branching of complex $\mathrm{N}$-glycans and therefore modulating galectin binding.

\section{Glycosylation in pregnancy, term, and preterm labor}

Protein glycosylation is of fundamental importance at all stages of human pregnancy from conception and implantation to delivery. Especially important are antennae sequences of Nand O-glycans which are potential ligands for lectins. Figure 3 displays the repertoire of glycan epitopes which are known to be expressed in the human male and female reproductive tracts. Both human gametes express functionally important glycoproteins. Glycoproteins of the extracellular matrix zona pellucida of the oocyte, present the sialyl-LexisX sequence [NeuAc $\alpha 2-3$ Gal $\beta 1-4$ (Fuc $\alpha 1-3$ )GlcNAc] as their major terminal structures on both $\mathrm{N}$ - and $\mathrm{O}-$ linked glycans. This terminal sialyl-LexisX sequence was shown to be the ligand that mediated sperm-egg binding [144].

Characterization of human sperm $\mathrm{N}$-glycans identified high mannose, biantennary complex glycans with bisecting GlcNAc and multi-antennary complex $\mathrm{N}$-glycans with LewisX and LewisY [Fuc $\alpha 1-2 \mathrm{Gal} \beta 1-4$ (Fuc $\alpha 1-3)$ GlcNAc] sequences. Such N-glycan structural features have been associated with inhibition of both the adaptive and innate immune systems [145]. High levels of LewisX and LewisY sequences were also observed on human seminal plasma $\mathrm{N}$-glycans (and O-glycans), but levels of biantennary complex glycans with bisecting GlcNAc were reduced. This altered glycosylation profile would be more implicated with inhibition of the adaptive immune system and less so with inhibition of the innate could either block or enhance galectin binding. Abbreviations used in the figure: gal galactose; GlcNAc N- acetylglucosamine; NeuAc Neuraminic Acid; Fuc Fucose

immune response [146]. The presence of immunosuppressive glycans on sperm and in seminal plasma might function in improving fertilization outcomes [147].

Some of the most studied pregnancy-associated cell types are trophoblast cells, which are required for the formation and maintenance of the placenta and therefore functionally mediate the exchange of gases, transport of nutrients, and hormone production. There are different sub-types of trophoblast cells, EVT, which invade decidua and spiral arteries and are important in maintaining maternal blood supply into the placenta, syncytiotrophoblasts (STB), which are located on the villous surface and therefore are the primary cellular interface between the maternal blood supply and placental villi, and cytotrophoblasts (CTB), which are located just below the STBs. Glycomic characterization of the N-glycans of these cells revealed both common and differential glycan structural features. All three cell types expressed abundant high mannose glycans and dominance of $\alpha 2-3$ linked sialylated glycans over $\alpha 2-6$ linked. All cell types also expressed complex biantennary glycans with bisecting GlcNAc, but levels in EVT were lower than in CTB and STB. In contrast, EVT expressed higher levels of multiantennary and polylactosamine extended complex Nglycans compared to CTB and STB. The $\alpha 2-3$ linked sialylated termini and the polylactosamine antennae are both potential ligands for galectins.

A genome-wide association study (GWAS) has found that slit guidance ligand 2-roundabout guidance receptor 1 (SLIT2-ROBO1) signaling in trophoblasts is associated with PTB and that higher mRNA levels of SLIT2 and ROBO1 are detected in the basal plate of placentas from PTB samples [148]. Interestingly, knockdown of $R O B O 1$ in trophoblast- 
derived cells upregulated 6 of 10 pregnancy-specific glycoproteins (PSGs). PSGs are members of the immunoglobulin superfamily and are produced by trophoblast cells and pass into the maternal blood supply during pregnancy. All 10 PSGs have been implicated in immunomodulatory functions [149] and are important for the maintenance of normal pregnancy [150]. PSGs contain multiple potential N-glycosylation sequences and also potential sites for O-glycosylation and evidence of glycosylation have been indicated by lectin binding studies [151]. Recently, we have characterized PSG1 n detail in terms of its glycosylation [152]. We showed that PSG1 contains multi-antennary complex $\mathrm{N}$-glycans with high levels of $\alpha 2-3$ sialic acid capping. Low levels of $\mathrm{N}$-glycans with bisecting GlcNAc were also observed. In addition, we demonstrated that PSG1 specifically interacts with gal-1-1 with an estimated $\mathrm{K}_{\mathrm{D}}$ of $0.13 \mathrm{uM}$. Of potential functional importance, the binding of PSG1 by gal-1 protected it from oxidative inactivation.

The best-characterized pregnancy-associated glycoprotein in amniotic fluid is glycodelin A (GdA), which is a member of the lipocalin family of proteins. Lipocalins are a large family of small proteins that share tertiary structures and, except for glycodelin, typically transport or store small biological compounds such as vitamins and steroid hormones. Schiefner et al. [153] have determined the crystal structure of GdA and showed that it forms a dimer that presents its $\mathrm{N}$-glycans in an array format conducive to high-affinity lectin binding. Interestingly the glycodelin gene has only been found in humans and higher primates and Schiefner et al. have pointed out that the occurrence of glycodelin coincides with the evolution of menstruation in higher primates. The detailed structural characterization of GdA N-glycosylation showed that two of the three potential N-glycosylation sites are occupied and that there is site-specific glycosylation. Asn-28 carries high mannose, hybrid, and complex-type structures whereas Asn-63 exclusively carries complex glycans [154]. Subsequent analyses using more sensitive mass spectrometry methodologies revealed the presence of a more complex glycome including tri- and tetra- antennary complex structures carrying the Sda epitope (NeuAc $\alpha 2-3$ (GalNAc $\beta 1-$ 4)Gal)[155]. Interestingly, it has also been demonstrated that GdA from women with gestational diabetes mellitus (GDM) have altered $\mathrm{N}$-glycan structures with reduced levels of $\alpha 2-6$ sialylation and high mannose glycans and an increase in levels of Sda epitopes. These glycosylation changes correlated with reduced immunosuppressive activity in in vitro assays [156]. It has recently been reported that the odds of PTB are $30 \%$ higher in women with GDM [157].

T cells are a well-defined target of GdA. GdA has been discovered to inhibit $\mathrm{T}$ cell proliferation in response to allogeneic antigens [158] and induce apoptosis of activated
T cells [159]. Chronic chorioamnionitis (CCA) is the process of amniotropic infiltration of maternal $\mathrm{T}$ cells, which can break maternal/fetal tolerance and lead to maternal anti-fetal allograft rejection [160]. CCA is one of the major placental lesions of spontaneous preterm birth and is considered as the most common pathology of late preterm birth [161]. Proteomic analysis of amniotic fluid samples has found that GdA is significantly lower in CCA, compared to the samples from acute chorioamnionitis and gestational age-matched controls [162]. These results suggest a pathophysiological link between preterm birth and GdA. The glycans on GdA may be associated with maternal tolerance to fetal antigens and PTB.

Human chorionic gonadotropin (hCG) is another essential pregnancy-associated glycoprotein. Recent glycomic studies have shown that hCG from pregnant women corresponded to mono-, bi-, tri-, and tetra-antennary N-glycans. There was also a substantial amount of bisected $\mathrm{N}$ - glycan structures with abundant LewisX capping. Interestingly hCG from women later diagnosed with pre-eclampsia also showed a high abundance of sialylated bi-antennary N-glycans [163].

Dynamic changes in cervical glycosaminoglycans (GAGs) have been found during pregnancy [164]. Six types of GAGs have been identified: hyaluronan (HA), dermatan sulfate (DS), keratan sulfate (KS), chondroitin sulfate (CS), heparin, and heparan sulfate (HS). However, HA exclusively increases from $19 \%$ in early pregnancy to $71 \%$ at term. In addition, the size of HA decreases in labor, due to higher activity of HA digesting enzyme hyaluronidase. The changes of HA during pregnancy are hypothesized to contribute to cervical ripening for term and PTB.

A potential cause of PTB are infections ascending from the vagina to the intrauterine cavity through the cervical tube [4]. The change of permeability of the cervical tube is related to preterm birth [165]. Mucin glycoproteins are a major constituent of mucus along the cervical tube, which functions as a physical barrier against ascending bacteria. These proteins are extensively O-glycosylated and the Oglycans are heavily clustered in Ser/Thr rich domains, which are separated by short non-glycosylated regions. These O-glycan chains can be terminated by ABO blood groups, Lewis antigens, and sialic acid. As glycans can be used as receptors by many bacterial adhesins during infection, the change of cervical mucus glycans could alter the microbiome in the intrauterine cavity.

\section{Concluding remarks and future perspectives}

Current evidences have established that galectins have multiple roles in healthy gestation and regulate the immune response during infections. However, our understating of the role of galectins in parturition is scarce and key 
priorities to further reveal their contribution include (1) defining the galectin signature during healthy parturition and preterm labor, (2) delineation of the mechanism (e.g., glycan structures) by which galectins regulate ascending infections and orchestrate the immune response against microbes, and (3) identifying galectins as possible regulators of cervical remodeling and uterine senescence that may predispose to cervical dysfunction and preterm labor in women. Focused studies in animal models and human tissue are likely to reveal the galectin-glycans circuits over the onset of labor and post-partum tissue repair.

Funding information Open Access funding provided by Projekt DEAL. The writing of this review was supported by the Deutsche Forschungsgemeinschaft (BL1115/2-1, BL1115/4-1, and Heisenberg program BL1115/7-1) to S.M.B. A.D., S.M.H. and G.W. would like to acknowledge funding from The March of Dimes European Preterm Birth Research Centre at Imperial College London.

\section{Compliance with ethical standards}

Conflict of Interest The authors declare that they have no conflict of interest.

Open Access This article is licensed under a Creative Commons Attribution 4.0 International License, which permits use, sharing, adaptation, distribution and reproduction in any medium or format, as long as you give appropriate credit to the original author(s) and the source, provide a link to the Creative Commons licence, and indicate if changes were made. The images or other third party material in this article are included in the article's Creative Commons licence, unless indicated otherwise in a credit line to the material. If material is not included in the article's Creative Commons licence and your intended use is not permitted by statutory regulation or exceeds the permitted use, you will need to obtain permission directly from the copyright holder. To view a copy of this licence, visit http://creativecommons. org/licenses/by/4.0/.

\section{References}

1. Blois SM, Dveksler G, Vasta GR, Freitag N, Blanchard V, Barrientos G (2019) Pregnancy galectinology: insights into a complex network of glycan binding proteins. Front Immunol 10:1166. https://doi.org/10.3389/fimmu.2019.01166

2. Vasta GR, Feng C, Gonzalez-Montalban N, Mancini J, Yang L, Abernathy K, Frost G, Palm C (2017) Functions of galectins as 'self/non-self'-recognition and effector factors. Pathogens Dis 75(5). https://doi.org/10.1093/femspd/ftx046

3. Watts DH, Krohn MA, Hillier SL, Eschenbach DA (1992) The association of occult amniotic fluid infection with gestational age and neonatal outcome among women in preterm labor. Obstet Gynecol 79(3):351-357. https://doi.org/10.1097/00006250199203000-00005

4. Goldenberg RL, Hauth JC, Andrews WW (2000) Intrauterine infection and preterm delivery. N Engl J Med 342(20):1500-1507

5. Barondes SH, Castronovo V, Cooper DN, Cummings RD, Drickamer K, Feizi T, Gitt MA, Hirabayashi J, Hughes C, Kasai K et al (1994) Galectins: a family of animal beta-galactoside- binding lectins. Cell 76(4):597-598. https://doi.org/10.1016/ 0092-8674(94)90498-7

6. Than NG, Romero R, Balogh A, Karpati E, Mastrolia SA, StaretzChacham O, Hahn S, Erez O, Papp Z, Kim CJ (2015) Galectins: double-edged swords in the cross-roads of pregnancy complications and female reproductive tract inflammation and neoplasia. J Pathol Translat Med 49(3):181-208. https://doi.org/10.4132/jptm. 2015.02.25

7. Liu FT, Patterson RJ, Wang JL (2002) Intracellular functions of galectins. Biochim Biophys Acta 1572(2-3):263-273

8. Hernandez JD, Baum LG (2002) Ah, sweet mystery of death! Galectins and control of cell fate. Glycobiology 12(10):127R136R

9. Nickel W (2005) Unconventional secretory routes: direct protein export across the plasma membrane of mammalian cells. Traffic (Copenhagen, Denmark) 6(8):607-614

10. He J, Baum LG (2006) Galectin interactions with extracellular matrix and effects on cellular function. Methods Enzymol 417: 247-256. https://doi.org/10.1016/S0076-6879(06)17017-2

11. Ochieng J, Furtak V, Lukyanov P (2002) Extracellular functions of galectin-3. Glycoconj J 19(7-9):527-535. https://doi.org/10. 1023/B:GLYC.0000014082.99675.2f

12. Fred Brewer C (2002) Binding and cross-linking properties of galectins. Biochim Biophys Acta 1572(2-3):255-262. https://doi. org/10.1016/s0304-4165(02)00312-4

13. Yang RY, Rabinovich GA, Liu FT (2008) Galectins: structure, function and therapeutic potential. Expert Rev Mol Med 10:e17. https://doi.org/10.1017/S1462399408000719

14. Cummings RD, Liu FT, Vasta GR (2015) Galectins. In: RD, Varki A, Cummings RD et al. (eds) Essentials of glycobiology. Cold Spring Harbor (NY), pp 469-480. doi:https://doi.org/10.1101/ glycobiology. $3 \mathrm{e} .036$

15. Blois SM, Ilarregui JM, Tometten M, Garcia M, Orsal AS, CordoRusso R, Toscano MA, Bianco GA, Kobelt P, Handjiski B, Tirado I, Markert UR, Klapp BF, Poirier F, Szekeres-Bartho J, Rabinovich GA, Arck PC (2007) A pivotal role for galectin-1 in fetomaternal tolerance. Nat Med 13(12):1450-1457

16. Rabinovich GA, Toscano MA (2009) Turning 'sweet' on immunity: galectin-glycan interactions in immune tolerance and inflammation. Nat Rev Immunol 9(5):338-352. https://doi.org/10.1038/ nri2536

17. Liu FT, Rabinovich GA (2010) Galectins: regulators of acute and chronic inflammation. Ann N Y Acad Sci 1183:158-182. https:// doi.org/10.1111/j.1749-6632.2009.05131.x

18. Sato S, St-Pierre C, Bhaumik P, Nieminen J (2009) Galectins in innate immunity: dual functions of host soluble beta-galactosidebinding lectins as damage-associated molecular patterns (DAMPs) and as receptors for pathogen-associated molecular patterns (PAMPs). Immunol Rev 230(1):172-187. https://doi.org/10. 1111/j.1600-065X.2009.00790.X

19. von Wolff M, Wang X, Gabius HJ, Strowitzki T (2005) Galectin fingerprinting in human endometrium and decidua during the menstrual cycle and in early gestation. Mol Hum Reprod 11(3): 189-194

20. Shimizu Y, Kabir-Salmani M, Azadbakht M, Sugihara K, Sakai K, Iwashita M (2008) Expression and localization of galectin-9 in the human uterodome. Endocr J 55(5):879-887

21. Popovici RM, Krause MS, Germeyer A, Strowitzki T, von Wolff M (2005) Galectin-9: a new endometrial epithelial marker for the mid- and late-secretory and decidual phases in humans. J Clin Endocrinol Metab 90(11):6170-6176

22. Yang H, Lei C, Zhang W (2012) Expression of galectin-3 in mouse endometrium and its effect during embryo implantation. Reprod BioMed Online 24(1):116-122. https://doi.org/10.1016/j. rbmo.2011.09.003 
23. Ochieng J, Leite-Browning ML, Warfield P (1998) Regulation of cellular adhesion to extracellular matrix proteins by galectin-3. Biochem Biophys Res Commun 246(3):788-791. https://doi.org/ 10.1006/bbrc.1998.8708

24. Tirado-Gonzalez I, Freitag N, Barrientos G, Shaikly V, Nagaeva O, Strand M, Kjellberg L, Klapp BF, Mincheva-Nilsson L, Cohen M, Blois SM (2013) Galectin-1 influences trophoblast immune evasion and emerges as a predictive factor for the outcome of pregnancy. Mol Hum Reprod 19(1):43-53

25. Jeschke U, Karsten U, Wiest I, Schulze S, Kuhn C, Friese K, Walzel H (2006) Binding of galectin-1 (gal-1) to the ThomsenFriedenreich (TF) antigen on trophoblast cells and inhibition of proliferation of trophoblast tumor cells in vitro by gal-1 or an antiTF antibody. Histochem Cell Biol 126(4):437-444. https://doi. org/10.1007/s00418-006-0178-1

26. Aplin JD (1997) Adhesion molecules in implantation. Rev Reprod 2(2):84-93. https://doi.org/10.1530/ror.0.0020084

27. Lei CX, Zhang W, Zhou JP, Liu YK (2009) Interactions between galectin-3 and integrinbeta3 in regulating endometrial cell proliferation and adhesion. Human Reproduct (Oxford, England) 24(11):2879-2889. https://doi.org/10.1093/humrep/dep250

28. Ander SE, Diamond MS, Coyne CB (2019) Immune responses at the maternal-fetal interface. Sci Immunol 4(31). https://doi.org/10. 1126/sciimmunol.aat6114

29. Koopman LA, Kopcow HD, Rybalov B, Boyson JE, Orange JS, Schatz F, Masch R, Lockwood CJ, Schachter AD, Park PJ, Strominger JL (2003) Human decidual natural killer cells are a unique NK cell subset with immunomodulatory potential. J Exp Med 198(8):1201-1212

30. Than NG, Romero R, Erez O, Weckle A, Tarca AL, Hotra J, Abbas A, Han YM, Kim SS, Kusanovic JP, Gotsch F, Hou Z, Santolaya-Forgas J, Benirschke K, Papp Z, Grossman LI, Goodman M, Wildman DE (2008) Emergence of hormonal and redox regulation of galectin-1 in placental mammals: implication in maternal-fetal immune tolerance. Proc Natl Acad Sci U S A 105(41):15819-15824

31. Erlebacher A (2013) Mechanisms of T cell tolerance towards the allogeneic fetus. Nat Rev Immunol 13(1):23-33. https://doi.org/ $10.1038 /$ nri3361

32. Than NG, Romero R, Goodman M, Weckle A, Xing J, Dong Z, Xu Y, Tarquini F, Szilagyi A, Gal P, Hou Z, Tarca AL, Kim CJ, Kim JS, Haidarian S, Uddin M, Bohn H, Benirschke K, Santolaya-Forgas J, Grossman LI, Erez O, Hassan SS, Zavodszky P, Papp Z, Wildman DE (2009) A primate subfamily of galectins expressed at the maternal-fetal interface that promote immune cell death. Proc Natl Acad Sci U S A 106(24):9731-9736

33. Balogh A, Toth E, Romero R, Parej K, Csala D, Szenasi NL, Hajdu I, Juhasz K, Kovacs AF, Meiri H, Hupuczi P, Tarca AL, Hassan SS, Erez O, Zavodszky P, Matko J, Papp Z, Rossi SW, Hahn S, Pallinger E, Than NG (2019) Placental galectins are key players in regulating the maternal adaptive immune response. Front Immunol 10:1240. https://doi.org/10.3389/fimmu.2019. 01240

34. Toscano MA, Bianco GA, Ilarregui JM, Croci DO, Correale J, Hernandez JD, Zwirner NW, Poirier F, Riley EM, Baum LG, Rabinovich GA (2007) Differential glycosylation of TH1, TH2 and TH-17 effector cells selectively regulates susceptibility to cell death. Nat Immunol 8(8):825-834

35. Hunt JS, Langat DK, McIntire RH, Morales PJ (2006) The role of HLA-G in human pregnancy. Reprod Biol Endocrinol 4 Suppl 1: S10. https://doi.org/10.1186/1477-7827-4-S1-S10

36. Li YH, Zhou WH, Tao Y, Wang SC, Jiang YL, Zhang D, Piao HL, Fu Q, Li DJ, Du MR (2016) The Galectin-9/Tim-3 pathway is involved in the regulation of $\mathrm{NK}$ cell function at the maternal-fetal interface in early pregnancy. Cell Mol Immunol 13(1):73-81. https://doi.org/10.1038/cmi.2014.126
37. Zhu C, Anderson AC, Schubart A, Xiong H, Imitola J, Khoury SJ, Zheng XX, Strom TB, Kuchroo VK (2005) The Tim-3 ligand galectin- 9 negatively regulates $\mathrm{T}$ helper type 1 immunity. Nat Immunol 6(12):1245-1252. https://doi.org/10.1038/ni1271

38. Kopcow HD, Rosetti F, Leung Y, Allan DS, Kutok JL, Strominger JL (2008) T cell apoptosis at the maternal-fetal interface in early human pregnancy, involvement of galectin-1. Proc Natl Acad Sci U S A 105(47):18472-18477

39. Heusschen R, Freitag N, Tirado-Gonzalez I, Barrientos G, Moschansky P, Munoz-Fernandez R, Leno-Duran E, Klapp BF, Thijssen VL, Blois SM (2013) Profiling Lgals9 splice variant expression at the fetal-maternal interface: implications in normal and pathological human pregnancy. Biol Reprod 88(1):22

40. Ilarregui JM, Croci DO, Bianco GA, Toscano MA, Salatino M, Vermeulen ME, Geffner JR, Rabinovich GA (2009) Tolerogenic signals delivered by dendritic cells to $T$ cells through a galectin-1driven immunoregulatory circuit involving interleukin 27 and interleukin 10. Nat Immunol 10(9):981-991

41. Friebe A, Douglas AJ, Solano E, Blois SM, Hagen E, Klapp BF, Clark DA, Arck PC (2011) Neutralization of LPS or blockage of TLR4 signaling prevents stress-triggered fetal loss in murine pregnancy. J Mol Med (Berl) 89(7):689-699

42. Blois SM, Conrad ML, Freitag N, Barrientos G (2015) Galectins in angiogenesis: consequences for gestation. J Reprod Immunol 108:33-41

43. Thijssen VL, Barkan B, Shoji H, Aries IM, Mathieu V, Deltour L, Hackeng TM, Kiss R, Kloog Y, Poirier F, Griffioen AW (2010) Tumor cells secrete galectin-1 to enhance endothelial cell activity. Cancer Res 70(15):6216-6224

44. Hsieh SH, Ying NW, Wu MH, Chiang WF, Hsu CL, Wong TY, Jin YT, Hong TM, Chen YL (2008) Galectin-1, a novel ligand of neuropilin-1, activates VEGFR-2 signaling and modulates the migration of vascular endothelial cells. Oncogene 27(26):3746-3753

45. Douglas NC, Tang H, Gomez R, Pytowski B, Hicklin DJ, Sauer CM, Kitajewski J, Sauer MV, Zimmermann RC (2009) Vascular endothelial growth factor receptor 2 (VEGFR-2) functions to promote uterine decidual angiogenesis during early pregnancy in the mouse. Endocrinology 150(8):3845-3854

46. Halder JB, Zhao X, Soker S, Paria BC, Klagsbrun M, Das SK, Dey SK (2000) Differential expression of VEGF isoforms and VEGF(164)-specific receptor neuropilin-1 in the mouse uterus suggests a role for $\operatorname{VEGF}(164)$ in vascular permeability and angiogenesis during implantation. Genesis 26(3):213-224

47. Freitag N, Tirado-Gonzalez I, Barrientos G, Herse F, Thijssen VL, Weedon-Fekjaer SM, Schulz H, Wallukat G, Klapp BF, Nevers T, Sharma S, Staffy AC, Dechend R, Blois SM (2013) Interfering with Gal-1-mediated angiogenesis contributes to the pathogenesis of preeclampsia. Proc Natl Acad Sci U S A 110(28):1145111456. https://doi.org/10.1073/pnas.1303707110

48. Kliman HJ, Sammar M, Grimpel YI, Lynch SK, Milano KM, Pick E, Bejar J, Arad A, Lee JJ, Meiri H, Gonen R (2012) Placental protein 13 and decidual zones of necrosis: an immunologic diversion that may be linked to preeclampsia. Reproduct Sci (Thousand Oaks, Calif) 19(1):16-30

49. Gizurarson S, Huppertz B, Osol G, Skarphedinsson JO, Mandala M, Meiri H (2013) Effects of placental protein 13 on the cardiovascular system in gravid and non-gravid rodents. Fetal Diagn Ther 33(4):257-264

50. Drobnjak T, Gizurarson S, Gokina NI, Meiri H, Mandala M, Huppertz B, Osol G (2017) Placental protein 13 (PP13)-induced vasodilation of resistance arteries from pregnant and nonpregnant rats occurs via endothelial-signaling pathways. Hypertens Pregnancy 36(2):186-195. https://doi.org/10.1080/10641955. 2017.1295052

51. Gizurarson S, Sigurdardottir ER, Meiri H, Huppertz B, Sammar M, Sharabi-Nov A, Mandala M, Osol G (2016) Placental protein 
13 administration to pregnant rats lowers blood pressure and augments fetal growth and venous remodeling. Fetal Diagn Ther 39(1):56-63. https://doi.org/10.1159/000381914

52. El-Azzamy H, Balogh A, Romero R, Xu Y, LaJeunesse C, Plazyo O, Xu Z, Price TG, Dong Z, Tarca AL, Papp Z, Hassan SS, Chaiworapongsa T, Kim CJ, Gomez-Lopez N, Than NG (2017) Characteristic changes in decidual gene expression signature in spontaneous term parturition. J Pathol Translat Med 51(3):264 283. https://doi.org/10.4132/jptm.2016.12.20

53. Enninga EAL, Harrington SM, Creedon DJ, Ruano R, Markovic SN, Dong H, Dronca RS (2018) Immune checkpoint molecules soluble program death ligand 1 and galectin- 9 are increased in pregnancy. Am J Reprod Immunol 79(2). https://doi.org/10. 1111/aji.12795

54. Phillips B, Knisley K, Weitlauf KD, Dorsett J, Lee V, Weitlauf H (1996) Differential expression of two beta-galactoside-binding lectins in the reproductive tracts of pregnant mice. Biol Reprod 55(3):548-558

55. Collaborators GBDRF, Forouzanfar MH, Alexander L, Anderson HR, Bachman VF, Biryukov S, Brauer M, Burnett R, Casey D, Coates MM, Cohen A, Delwiche K, Estep K, Frostad JJ, Astha KC, Kyu HH, Moradi-Lakeh M, Ng M, Slepak EL, Thomas BA, Wagner J, Aasvang GM, Abbafati C, Abbasoglu Ozgoren A, AbdAllah F, Abera SF, Aboyans V, Abraham B, Abraham JP, Abubakar I, Abu-Rmeileh NM, Aburto TC, Achoki T, Adelekan A, Adofo K, Adou AK, Adsuar JC, Afshin A, Agardh EE, Al Khabouri MJ, Al Lami FH, Alam SS, Alasfoor D, Albittar MI, Alegretti MA, Aleman AV, Alemu ZA, Alfonso-Cristancho R, Alhabib S, Ali R, Ali MK, Alla F, Allebeck P, Allen PJ, Alsharif U, Alvarez E, Alvis-Guzman N, Amankwaa AA, Amare AT, Ameh EA, Ameli O, Amini H, Ammar W, Anderson BO, Antonio CA, Anwari P, Argeseanu Cunningham S, Arnlov J, Arsenijevic VS, Artaman A, Asghar RJ, Assadi R, Atkins LS, Atkinson C, Avila MA, Awuah B, Badawi A, Bahit MC, Bakfalouni T, Balakrishnan K, Balalla S, Balu RK, Banerjee A, Barber RM, Barker-Collo SL, Barquera S, Barregard L, Barrero LH, Barrientos-Gutierrez T, Basto-Abreu AC, Basu A, Basu S, Basulaiman MO, Batis Ruvalcaba C, Beardsley J, Bedi N, Bekele T, Bell ML, Benjet C, Bennett DA, Benzian H, Bernabe E, Beyene TJ, Bhala N, Bhalla A, Bhutta ZA, Bikbov B, Bin Abdulhak AA, Blore JD, Blyth FM, Bohensky MA, Bora Basara B, Borges G, Bornstein NM, Bose D, Boufous S, Bourne RR, Brainin M, Brazinova A, Breitborde NJ, Brenner H, Briggs AD, Broday DM, Brooks PM, Bruce NG, Brugha TS, Brunekreef B, Buchbinder R, Bui LN, Bukhman G, Bulloch AG, Burch M, Burney PG, Campos-Nonato IR, Campuzano JC, Cantoral AJ, Caravanos J, Cardenas R, Cardis E, Carpenter DO, Caso V, Castaneda-Orjuela CA, Castro RE, Catala-Lopez F, Cavalleri F, Cavlin A, Chadha VK, Chang JC, Charlson FJ, Chen H, Chen W, Chen Z, Chiang PP, Chimed-Ochir O, Chowdhury R, Christophi CA, Chuang TW, Chugh SS, Cirillo M, Classen TK, Colistro V, Colomar M, Colquhoun SM, Contreras AG, Cooper C, Cooperrider K, Cooper LT, Coresh J, Courville KJ, Criqui MH, Cuevas-Nasu L, Damsere-Derry J, Danawi H, Dandona L, Dandona R, Dargan PI, Davis A, Davitoiu DV, Dayama A, de Castro EF, De la Cruz-Gongora V, De Leo D, de Lima G, Degenhardt L, del Pozo-Cruz B, Dellavalle RP, Deribe K, Derrett S, Des Jarlais DC, Dessalegn M, deVeber GA, Devries KM, Dharmaratne SD, Dherani MK, Dicker D, Ding EL, Dokova K, Dorsey ER, Driscoll TR, Duan L, Durrani AM, Ebel BE, Ellenbogen RG, Elshrek YM, Endres M, Ermakov SP, Erskine HE, Eshrati B, Esteghamati A, Fahimi S, Faraon EJ, Farzadfar F, Fay DF, Feigin VL, Feigl AB, Fereshtehnejad SM, Ferrari AJ, Ferri CP, Flaxman AD, Fleming TD, Foigt N, Foreman KJ, Paleo UF, Franklin RC, Gabbe B, Gaffikin L, Gakidou E, Gamkrelidze A, Gankpe FG, Gansevoort RT, Garcia-Guerra FA,
Gasana E, Geleijnse JM, Gessner BD, Gething P, Gibney KB, Gillum RF, Ginawi IA, Giroud M, Giussani G, Goenka S, Goginashvili K, Gomez Dantes H, Gona P, Gonzalez de Cosio T, Gonzalez-Castell D, Gotay CC, Goto A, Gouda HN, Guerrant RL, Gugnani HC, Guillemin F, Gunnell D, Gupta R, Gupta R, Gutierrez RA, Hafezi-Nejad N, Hagan H, Hagstromer M, Halasa YA, Hamadeh RR, Hammami M, Hankey GJ, Hao Y, Harb HL, Haregu TN, Haro JM, Havmoeller R, Hay SI, Hedayati MT, Heredia-Pi IB, Hernandez L, Heuton KR, Heydarpour P, Hijar M, Hoek HW, Hoffman HJ, Hornberger JC, Hosgood HD, Hoy DG, Hsairi M, Hu G, Hu H, Huang C, Huang JJ, Hubbell BJ, Huiart L, Husseini A, Iannarone ML, Iburg KM, Idrisov BT, Ikeda $\mathrm{N}$, Innos $\mathrm{K}$, Inoue $\mathrm{M}$, Islami $\mathrm{F}$, Ismayilova $\mathrm{S}$, Jacobsen KH, Jansen HA, Jarvis DL, Jassal SK, Jauregui A, Jayaraman S, Jeemon P, Jensen PN, Jha V, Jiang F, Jiang G, Jiang Y, Jonas JB, Juel K, Kan H, Kany Roseline SS, Karam NE, Karch A, Karema CK, Karthikeyan G, Kaul A, Kawakami N, Kazi DS, Kemp AH, Kengne AP, Keren A, Khader YS, Khalifa SE, Khan EA, Khang YH, Khatibzadeh S, Khonelidze I, Kieling C, Kim D, Kim S, Kim Y, Kimokoti RW, Kinfu Y, Kinge JM, Kissela BM, Kivipelto M, Knibbs LD, Knudsen AK, Kokubo Y, Kose MR, Kosen S, Kraemer A, Kravchenko M, Krishnaswami S, Kromhout H, Ku T, Kuate Defo B, Kucuk Bicer B, Kuipers EJ, Kulkarni C, Kulkarni VS, Kumar GA, Kwan GF, Lai T, Lakshmana Balaji A, Lalloo R, Lallukka T, Lam H, Lan Q, Lansingh VC, Larson HJ, Larsson A, Laryea DO, Lavados PM, Lawrynowicz AE, Leasher JL, Lee JT, Leigh J, Leung R, Levi M, Li Y, Li Y, Liang J, Liang X, Lim SS, Lindsay MP, Lipshultz SE, Liu S, Liu Y, Lloyd BK, Logroscino G, London SJ, Lopez N, LortetTieulent J, Lotufo PA, Lozano R, Lunevicius R, Ma J, Ma S, Machado VM, MacIntyre MF, Magis-Rodriguez C, Mahdi AA, Majdan M, Malekzadeh R, Mangalam S, Mapoma CC, Marape M, Marcenes W, Margolis DJ, Margono C, Marks GB, Martin RV, Marzan MB, Mashal MT, Masiye F, Mason-Jones AJ, Matsushita K, Matzopoulos R, Mayosi BM, Mazorodze TT, McKay AC, McKee M, McLain A, Meaney PA, Medina C, Mehndiratta MM, Mejia-Rodriguez F, Mekonnen W, Melaku YA, Meltzer M, Memish ZA, Mendoza W, Mensah GA, Meretoja A, Mhimbira FA, Micha R, Miller TR, Mills EJ, Misganaw A, Mishra S, Mohamed Ibrahim N, Mohammad KA, Mokdad AH, Mola GL, Monasta L, Montanez Hernandez JC, Montico M, Moore AR, Morawska L, Mori R, Moschandreas J, Moturi WN, Mozaffarian D, Mueller UO, Mukaigawara M, Mullany EC, Murthy KS, Naghavi M, Nahas Z, Naheed A, Naidoo KS, Naldi L, Nand D, Nangia V, Narayan KM, Nash D, Neal B, Nejjari C, Neupane SP, Newton CR, Ngalesoni FN, Ngirabega Jde D, Nguyen G, Nguyen NT, Nieuwenhuijsen MJ, Nisar MI, Nogueira JR, Nolla JM, Nolte S, Norheim OF, Norman RE, Norrving B, Nyakarahuka L, Oh IH, Ohkubo T, Olusanya BO, Omer SB, Opio JN, Orozco R, Pagcatipunan RS Jr, Pain AW, Pandian JD, Panelo CI, Papachristou C, Park EK, Parry CD, Paternina Caicedo AJ, Patten SB, Paul VK, Pavlin BI, Pearce N, Pedraza LS, Pedroza A, Pejin Stokic L, Pekericli A, Pereira DM, Perez-Padilla R, Perez-Ruiz F, Perico N, Perry SA, Pervaiz A, Pesudovs K, Peterson CB, Petzold M, Phillips MR, Phua HP, Plass D, Poenaru D, Polanczyk GV, Polinder S, Pond CD, Pope CA, Pope D, Popova S, Pourmalek F, Powles J, Prabhakaran D, Prasad NM, Qato DM, Quezada AD, Quistberg DA, Racape L, Rafay A, Rahimi K, Rahimi-Movaghar V, Rahman SU, Raju M, Rakovac I, Rana SM, Rao M, Razavi H, Reddy KS, Refaat AH, Rehm J, Remuzzi G, Ribeiro AL, Riccio PM, Richardson L, Riederer A, Robinson M, Roca A, Rodriguez A, Rojas-Rueda D, Romieu I, Ronfani L, Room R, Roy N, Ruhago GM, Rushton L, Sabin N, Sacco RL, Saha S, Sahathevan R, Sahraian MA, Salomon JA, Salvo D, Sampson UK, Sanabria JR, Sanchez LM, Sanchez-Pimienta TG, Sanchez- 
Riera L, Sandar L, Santos IS, Sapkota A, Satpathy M, Saunders JE, Sawhney M, Saylan MI, Scarborough P, Schmidt JC, Schneider IJ, Schottker B, Schwebel DC, Scott JG, Seedat S, Sepanlou SG, Serdar B, Servan-Mori EE, Shaddick G, Shahraz S, Levy TS, Shangguan S, She J, Sheikhbahaei S, Shibuya K, Shin HH, Shinohara Y, Shiri R, Shishani K, Shiue I, Sigfusdottir ID, Silberberg DH, Simard EP, Sindi S, Singh A, Singh GM, Singh JA, Skirbekk V, Sliwa K, Soljak M, Soneji S, Soreide K, Soshnikov S, Sposato LA, Sreeramareddy CT, Stapelberg NJ, Stathopoulou V, Steckling N, Stein DJ, Stein MB, Stephens N, Stockl H, Straif K, Stroumpoulis K, Sturua L, Sunguya BF, Swaminathan S, Swaroop M, Sykes BL, Tabb KM, Takahashi K, Talongwa RT, Tandon N, Tanne D, Tanner M, Tavakkoli M, Te Ao BJ, Teixeira CM, Tellez Rojo MM, Terkawi AS, TexcalacSangrador JL, Thackway SV, Thomson B, Thorne-Lyman AL, Thrift AG, Thurston GD, Tillmann T, Tobollik M, Tonelli M, Topouzis F, Towbin JA, Toyoshima H, Traebert J, Tran BX, Trasande L, Trillini M, Trujillo U, Dimbuene ZT, Tsilimbaris M, Tuzcu EM, Uchendu US, Ukwaja KN, Uzun SB, van de Vijver S, Van Dingenen R, van Gool CH, van Os J, Varakin YY, Vasankari TJ, Vasconcelos AM, Vavilala MS, Veerman LJ, Velasquez-Melendez G, Venketasubramanian N, Vijayakumar L, Villalpando S, Violante FS, Vlassov VV, Vollset SE, Wagner GR, Waller SG, Wallin MT, Wan X, Wang H, Wang J, Wang L, Wang W, Wang Y, Warouw TS, Watts CH, Weichenthal S, Weiderpass E, Weintraub RG, Werdecker A, Wessells KR, Westerman R, Whiteford HA, Wilkinson JD, Williams HC, Williams TN, Woldeyohannes SM, Wolfe CD, Wong JQ, Woolf AD, Wright JL, Wurtz B, Xu G, Yan LL, Yang G, Yano Y, Ye P, Yenesew M, Yentur GK, Yip P, Yonemoto N, Yoon SJ, Younis MZ, Younoussi Z, Yu C, Zaki ME, Zhao Y, Zheng Y, Zhou M, Zhu J, Zhu S, Zou X, Zunt JR, Lopez AD, Vos T, Murray CJ (2015) Global, regional, and national comparative risk assessment of 79 behavioural, environmental and occupational, and metabolic risks or clusters of risks in 188 countries, 1990-2013: a systematic analysis for the Global Burden of Disease Study 2013. Lancet 386(10010):2287-2323. https://doi.org/10.1016/S0140-6736(15) 00128-2

56. Blencowe H, Cousens S, Oestergaard MZ, Chou D, Moller AB, Narwal R, Adler A, Vera Garcia C, Rohde S, Say L, Lawn JE (2012) National, regional, and worldwide estimates of preterm birth rates in the year 2010 with time trends since 1990 for selected countries: a systematic analysis and implications. Lancet 379(9832):2162-2172. https://doi.org/10.1016/S0140-6736(12) 60820-4

57. Blencowe H, Cousens S, Chou D, Oestergaard M, Say L, Moller AB, Kinney M, Lawn J Born too soon preterm birth action G (2013) born too soon: the global epidemiology of 15 million preterm births. Reprod Health 10 Suppl 1:S2. https://doi.org/10.1186/ 1742-4755-10-S1-S2

58. Lee AC, Blencowe H, Lawn JE (2019) Small babies, big numbers: global estimates of preterm birth. Lancet Glob Health 7(1):e2-e3. https://doi.org/10.1016/S2214-109X(18)30484-4

59. Limperopoulos C, Bassan H, Gauvreau K, Robertson RL Jr, Sullivan NR, Benson CB, Avery L, Stewart J, Soul JS, Ringer SA, Volpe JJ, duPlessis AJ (2007) Does cerebellar injury in premature infants contribute to the high prevalence of long-term cognitive, learning, and behavioral disability in survivors? Pediatrics 120(3):584-593. https://doi.org/10.1542/peds.2007-1041

60. Goldenberg RL, Culhane JF, Iams JD, Romero R (2008) Epidemiology and causes of preterm birth. Lancet (London, England) 371(9606):75-84. https://doi.org/10.1016/S01406736(08)60074-4

61. Romero R, Dey SK, Fisher SJ (2014) Preterm labor: one syndrome, many causes. Science 345(6198):760-765. https://doi. org/10.1126/science. 1251816
62. Moore RM, Mansour JM, Redline RW, Mercer BM, Moore JJ (2006) The physiology of fetal membrane rupture: insight gained from the determination of physical properties. Placenta 27(11-12): 1037-1051. https://doi.org/10.1016/j.placenta.2006.01.002

63. Shankar R, Johnson MP, Williamson NA, Cullinane F, Purcell AW, Moses EK, Brennecke SP (2010) Molecular markers of preterm labor in the choriodecidua. Reproduct Sci (Thousand Oaks, Calif) 17(3):297-310. https://doi.org/10.1177/ 1933719109353454

64. Fichorova RN, Yamamoto HS, Fashemi T, Foley E, Ryan S, Beatty N, Dawood H, Hayes GR, St-Pierre G, Sato S, Singh BN (2016) Trichomonas vaginalis lipophosphoglycan exploits binding to galectin-1 and -3 to modulate epithelial immunity. J Biol Chem 291(2):998-1013. https://doi.org/10.1074/jbc.M115. 651497

65. Gomez-Chavez F, Castro-Leyva V, Espejel-Nunez A, ZamoraMendoza RG, Rosas-Vargas H, Cancino-Diaz JC, Cancino-Diaz ME, Estrada-Gutierrez G, Rodriguez-Martinez S (2015) Galectin1 reduced the effect of LPS on the IL- 6 production in decidual cells by inhibiting LPS on the stimulation of IkappaBzeta. J Reprod Immunol 112:46-52. https://doi.org/10.1016/j.jri.2015. 07.002

66. Stefanoska I, Tadic J, Vilotic A, Jovanovic Krivokuca M, Abu Rabi T, Vicovac L (2017) Histological chorioamnionitis in preterm prelabor rupture of the membranes is associated with increased expression of galectin-3 by amniotic epithelium. J Matern Fetal Neonatal Med 30(18):2232-2236. https://doi.org/ 10.1080/14767058.2016.1243100

67. Romero R, Nicolaides KH, Conde-Agudelo A, O'Brien JM, Cetingoz E, Da Fonseca E, Creasy GW, Hassan SS (2016) Vaginal progesterone decreases preterm birth $</=34$ weeks of gestation in women with a singleton pregnancy and a short cervix: an updated meta-analysis including data from the OPPTIMUM study. Ultrasound Obstet Gynecol 48(3):308-317. https://doi. org/10.1002/uog. 15953

68. Arenas-Hernandez M, Romero R, Xu Y, Panaitescu B, GarciaFlores V, Miller D, Ahn H, Done B, Hassan SS, Hsu CD, Tarca AL, Sanchez-Torres C, Gomez-Lopez N (2019) Effector and Activated T Cells Induce Preterm Labor and Birth That Is Prevented by Treatment with Progesterone. J Immunol (Baltimore, Md : 1950) 202(9):2585-2608. https://doi.org/10. 4049/jimmunol.1801350

69. Choe YS, Shim C, Choi D, Lee CS, Lee KK, Kim K (1997) Expression of galectin-1 mRNA in the mouse uterus is under the control of ovarian steroids during blastocyst implantation. Mol Reprod Dev 48(2):261-266

70. Hirota Y, Burnum KE, Acar N, Rabinovich GA, Daikoku T, Dey SK (2012) Galectin-1 markedly reduces the incidence of resorptions in mice missing immunophilin FKBP52. Endocrinology 153(5):2486-2493

71. Kawai T, Akira S (2010) The role of pattern-recognition receptors in innate immunity: update on Toll-like receptors. Nat Immunol 11(5):373-384. https://doi.org/10.1038/ni.1863

72. Agrawal V, Hirsch E (2012) Intrauterine infection and preterm labor. Semin Fetal Neonatal Med 17(1):12-19. https://doi.org/ 10.1016/j.siny.2011.09.001

73. Mor G (2008) Inflammation and pregnancy: the role of toll-like receptors in trophoblast-immune interaction. Ann N Y Acad Sci 1127:121-128. https://doi.org/10.1196/annals.1434.006

74. Gonzalez JM, Xu H, Ofori E, Elovitz MA (2007) Toll-like receptors in the uterus, cervix, and placenta: is pregnancy an immunosuppressed state? Am J Obstet Gynecol 197(3):296 e291-296 e296. https://doi.org/10.1016/j.ajog.2007.06.021

75. Ma Y, Krikun G, Abrahams VM, Mor G, Guller S (2007) Cell type-specific expression and function of toll-like receptors 2 and 4 
in human placenta: implications in fetal infection. Placenta 28(10): 1024-1031

76. Patni S, Wynen LP, Seager AL, Morgan G, White JO, Thornton CA (2009) Expression and activity of Toll-like receptors 1-9 in the human term placenta and changes associated with labor at term. Biol Reprod 80(2):243-248. https://doi.org/10.1095/biolreprod. 108.069252

77. Koga K, Cardenas I, Aldo P, Abrahams VM, Peng B, Fill S, Romero R, Mor G (2009) Activation of TLR3 in the trophoblast is associated with preterm delivery. Am J Reprod Immunol 61(3): 196-212. https://doi.org/10.1111/j.1600-0897.2008.00682.x

78. Kim YM, Romero R, Chaiworapongsa T, Kim GJ, Kim MR, Kuivaniemi H, Tromp G, Espinoza J, Bujold E, Abrahams VM, Mor G (2004) Toll-like receptor-2 and -4 in the chorioamniotic membranes in spontaneous labor at term and in preterm parturition that are associated with chorioamnionitis. Am J Obstet Gynecol 191(4):1346-1355. https://doi.org/10.1016/j.ajog.2004.07.009

79. Abrahams VM, Aldo PB, Murphy SP, Visintin I, Koga K, Wilson G, Romero R, Sharma S, Mor G (2008) TLR6 modulates first trimester trophoblast responses to peptidoglycan. J Immunol 180(9):6035-6043. https://doi.org/10.4049/jimmunol.180.9.6035

80. Elovitz MA, Wang Z, Chien EK, Rychlik DF, Phillippe M (2003) A new model for inflammation-induced preterm birth: the role of platelet-activating factor and Toll-like receptor-4. Am J Pathol 163(5):2103-2111. https://doi.org/10.1016/S0002-9440(10) 63567-5

81. Wang H, Hirsch E (2003) Bacterially-induced preterm labor and regulation of prostaglandin-metabolizing enzyme expression in mice: the role of toll-like receptor 4. Biol Reprod 69(6):19571963. https://doi.org/10.1095/biolreprod.103.019620

82. Li L, Kang J, Lei W (2010) Role of Toll-like receptor 4 in inflammation-induced preterm delivery. Mol Hum Reprod 16(4):267-272. https://doi.org/10.1093/molehr/gap106

83. Adams Waldorf KM, Persing D, Novy MJ, Sadowsky DW, Gravett MG (2008) Pretreatment with toll-like receptor 4 antagonist inhibits lipopolysaccharide-induced preterm uterine contractility, cytokines, and prostaglandins in rhesus monkeys. Reprod Sci 15(2):121-127. https://doi.org/10.1177/1933719107310992

84. Robertson SA, Skinner RJ, Care AS (2006) Essential role for IL10 in resistance to lipopolysaccharide-induced preterm labor in mice. J Immunol 177(7):4888-4896. https://doi.org/10.4049/ jimmunol.177.7.4888

85. Terrone DA, Rinehart BK, Granger JP, Barrilleaux PS, Martin JN Jr, Bennett WA (2001) Interleukin-10 administration and bacterial endotoxin-induced preterm birth in a rat model. Obstet Gynecol 98(3):476-480. https://doi.org/10.1016/s0029-7844(01)01424-7

86. Cappelletti M, Presicce P, Lawson MJ, Chaturvedi V, Stankiewicz TE, Vanoni S, Harley IT, McAlees JW, Giles DA, MorenoFernandez ME, Rueda CM, Senthamaraikannan P, Sun X, Karns R, Hoebe K, Janssen EM, Karp CL, Hildeman DA, Hogan SP, Kallapur SG, Chougnet CA, Way SS, Divanovic S (2017) Type I interferons regulate susceptibility to inflammation-induced preterm birth. JCI Insight 2(5):e91288. https://doi.org/10.1172/jci. insight. 91288

87. Hardy JT, Buhimschi IA, McCarthy ME, Zhao G, Laky CA, Shook LL, Buhimschi CS (2016) Imbalance of Amniotic Fluid Activin-A and Follistatin in Intraamniotic Infection, Inflammation, and Preterm Birth. J Clin Endocrinol Metab 101(7):2785-2793. https://doi.org/10.1210/jc.2015-4147

88. Kindinger LM, MacIntyre DA, Lee YS, Marchesi JR, Smith A, McDonald JA, Terzidou V, Cook JR, Lees C, Israfil-Bayli F, Faiza Y, Toozs-Hobson P, Slack M, Cacciatore S, Holmes E, Nicholson JK, Teoh TG, Bennett PR (2016) Relationship between vaginal microbial dysbiosis, inflammation, and pregnancy outcomes in cervical cerclage. Sci Transl Med 8(350):350ra102. https://doi.org/10.1126/scitranslmed.aag1026
89. Romero R, Espinoza J, Goncalves LF, Kusanovic JP, Friel L, Hassan S (2007) The role of inflammation and infection in preterm birth. Semin Reprod Med 25(1):21-39. https://doi.org/10.1055/s2006-956773

90. Mendz GL, Kaakoush NO, Quinlivan JA (2013) Bacterial aetiological agents of intra-amniotic infections and preterm birth in pregnant women. Front Cell Infect Microbiol 3:58. https://doi. org/10.3389/fcimb.2013.00058

91. Subtil D, Brabant G, Tilloy E, Devos P, Canis F, Fruchart A, Bissinger MC, Dugimont JC, Nolf C, Hacot C, Gautier S, Chantrel J, Jousse M, Desseauve D, Plennevaux JL, Delaeter C, Deghilage S, Personne A, Joyez E, Guinard E, Kipnis E, Faure K, Grandbastien B, Ancel PY, Goffinet F, Dessein R (2018) Early clindamycin for bacterial vaginosis in pregnancy (PREMEVA): a multicentre, double-blind, randomised controlled trial. Lancet (London, England) 392(10160):2171-2179. https://doi.org/10. 1016/s0140-6736(18)31617-9

92. Brocklehurst P, Rooney G (2000) Interventions for treating genital chlamydia trachomatis infection in pregnancy. Cochrane Database Syst Rev (2):Cd000054. https://doi.org/10.1002/14651858. Cd000054

93. Haahr T, Ersboll AS, Karlsen MA, Svare J, Sneider K, Hee L, Weile LK, Ziobrowska-Bech A, Ostergaard C, Jensen JS, Helmig $\mathrm{RB}$, Uldbjerg N (2016) Treatment of bacterial vaginosis in pregnancy in order to reduce the risk of spontaneous preterm delivery a clinical recommendation. Acta Obstet Gynecol Scand 95(8): 850-860. https://doi.org/10.1111/aogs.12933

94. Yudin MH, Money DM (2008) Screening and management of bacterial vaginosis in pregnancy. J Obstet Gynaecol Can 30(8): 702-708. https://doi.org/10.1016/s1701-2163(16)32919-x

95. Reekie J, Roberts C, Preen D, Hocking JS, Donovan B, Ward J, Mak DB, Liu B (2018) Chlamydia trachomatis and the risk of spontaneous preterm birth, babies who are born small for gestational age, and stillbirth: a population-based cohort study. Lancet Infect Dis 18(4):452-460. https://doi.org/10.1016/s14733099(18)30045-8

96. Ahmadi A, Ramazanzadeh R, Sayehmiri K, Sayehmiri F, Amirmozafari N (2018) Association of Chlamydia trachomatis infections with preterm delivery; a systematic review and metaanalysis. BMC Pregnancy Childbirth 18(1):240-240. https://doi. org/10.1186/s12884-018-1868-0

97. Bianchi-Jassir F, Seale AC, Kohli-Lynch M, Lawn JE, Baker CJ, Bartlett L, Cutland C, Gravett MG, Heath PT, Ip M, Le Doare K, Madhi SA, Saha SK, Schrag S, Sobanjo-Ter Meulen A, Vekemans J, Rubens CE (2017) Preterm Birth Associated With Group B Streptococcus Maternal Colonization Worldwide: Systematic Review and Meta-analyses. Clin Infect Dis 65(suppl_2):S133-s142. https://doi.org/10.1093/cid/cix661

98. Howe K, Kissinger PJ (2017) Single-Dose Compared With Multidose Metronidazole for the Treatment of Trichomoniasis in Women: A Meta-Analysis. Sex Transm Dis 44(1):29-34. https:// doi.org/10.1097/OLQ.0000000000000537

99. Vasta GR (2009) Roles of galectins in infection. Nat Rev Microbiol 7(6):424 438. https://doi.org/10.1038/nrmicro2146

100. Vasta GR (2020) Galectins in host-pathogen interactions: structural, functional and evolutionary aspects. Adv Exp Med Biol 1204: 169-196. https://doi.org/10.1007/978-981-15-1580-4_7

101. Cerliani JP, Stowell SR, Mascanfroni ID, Arthur CM, Cummings RD, Rabinovich GA (2011) Expanding the universe of cytokines and pattern recognition receptors: galectins and glycans in innate immunity. J Clin Immunol 31(1):10-21. https://doi.org/10.1007/ s10875-010-9494-2

102. Singh BN, Hayes GR, Lucas JJ, Sommer U, Viseux N, Mirgorodskaya E, Trifonova RT, Sassi RR, Costello CE, Fichorova RN (2009) Structural details and composition of Trichomonas vaginalis lipophosphoglycan in relevance to the 
epithelial immune function. Glycoconj J 26(1):3-17. https://doi. org/10.1007/s10719-008-9157-1

103. Fichorova RN, Trifonova RT, Gilbert RO, Costello CE, Hayes GR, Lucas JJ, Singh BN (2006) Trichomonas vaginalis lipophosphoglycan triggers a selective upregulation of cytokines by human female reproductive tract epithelial cells. Infect Immun 74(10):5773-5779. https://doi.org/10.1128/iai.00631-06

104. Lujan AL, Croci DO, Gambarte Tudela JA, Losinno AD, Cagnoni AJ, Marino KV, Damiani MT, Rabinovich GA (2018) Glycosylation-dependent galectin-receptor interactions promote Chlamydia trachomatis infection. Proc Natl Acad Sci U S A 115(26):E6000-e6009. https://doi.org/10.1073/pnas.1802188115

105. Surve MV, Anil A, Kamath KG, Bhutda S, Sthanam LK, Pradhan A, Srivastava R, Basu B, Dutta S, Sen S, Modi D, Banerjee A (2016) Membrane vesicles of group B Streptococcus disrupt fetomaternal barrier leading to preterm birth. PLoS Pathog 12(9): e1005816. https://doi.org/10.1371/journal.ppat.1005816

106. Demmert M, Faust K, Bohlmann MK, Troger B, Gopel W, Herting E, Hartel C (2012) Galectin-3 in cord blood of term and preterm infants. Clin Exp Immunol 167(2):246-251. https://doi. org/10.1111/j.1365-2249.2011.04509.x

107. Imaizumi T, Yoshida H, Nishi N, Sashinami H, Nakamura T, Hirashima M, Ohyama C, Itoh K, Satoh K (2007) Doublestranded RNA induces galectin-9 in vascular endothelial cells: involvement of TLR3, PI3K, and IRF3 pathway. Glycobiology 17(7):12C-15C. https://doi.org/10.1093/glycob/cwm045

108. Pearson MJ, Bik MA, Ospelt C, Naylor AJ, Wehmeyer C, Jones SW, Buckley CD, Gay S, Filer A, Lord JM (2018) Endogenous galectin-9 suppresses apoptosis in human rheumatoid arthritis synovial fibroblasts. Sci Rep 8(1):12887. https://doi.org/10.1038/ s41598-018-31173-3

109. Harwood NM, Golden-Mason L, Cheng L, Rosen HR, Mengshol JA (2016) HCV-infected cells and differentiation increase monocyte immunoregulatory galectin-9 production. J Leukoc Biol 99(3):495-503. https://doi.org/10.1189/jlb.5A1214-582R

110. Arad U, Madar-Balakirski N, Angel-Korman A, Amir S, Tzadok S, Segal O, Menachem A, Gold A, Elkayam O, Caspi D (2015) Galectin-3 is a sensor-regulator of toll-like receptor pathways in synovial fibroblasts. Cytokine 73(1):30-35. https://doi.org/10. 1016/j.cyto.2015.01.016

111. Cobb CM, Kelly PJ, Williams KB, Babbar S, Angolkar M, Derman RJ (2017) The oral microbiome and adverse pregnancy outcomes. Int J Women's Health 9:551-559. https://doi.org/10. 2147/IJWH.S142730

112. Arce RM, Barros SP, Wacker B, Peters B, Moss K, Offenbacher S (2009) Increased TLR4 expression in murine placentas after oral infection with periodontal pathogens. Placenta 30(2):156-162. https://doi.org/10.1016/j.placenta.2008.11.017

113. Konishi H, Urabe S, Miyoshi H, Teraoka Y, Maki T, Furusho H, Miyauchi M, Takata T, Kudo Y, Kajioka S (2019) Fetal membrane inflammation induces preterm birth via toll-like receptor 2 in mice with chronic gingivitis. Reprod Sci 26(7):869-878. https:// doi.org/10.1177/1933719118792097

114. Hasegawa-Nakamura K, Tateishi F, Nakamura T, Nakajima Y, Kawamata K, Douchi T, Hatae M, Noguchi K (2011) The possible mechanism of preterm birth associated with periodontopathic Porphyromonas gingivalis. J Periodontal Res 46(4):497-504. https://doi.org/10.1111/j.1600-0765.2011.01366.x

115. Miyauchi M, Ao M, Furusho H, Chea C, Nagasaki A, Sakamoto S, Ando T, Inubushi T, Kozai K, Takata T (2018) Galectin-3 plays an important role in preterm birth caused by dental infection of Porphyromonas gingivalis. Sci Rep 8(1):2867. https://doi.org/10. 1038/s41598-018-21072-y

116. Burguillos MA, Svensson M, Schulte T, Boza-Serrano A, GarciaQuintanilla A, Kavanagh E, Santiago M, Viceconte N, OlivaMartin MJ, Osman AM, Salomonsson E, Amar L, Persson A,
Blomgren K, Achour A, Englund E, Leffler H, Venero JL, Joseph B, Deierborg T (2015) Microglia-secreted galectin-3 acts as a toll-like receptor 4 ligand and contributes to microglial activation. Cell Rep 10(9):1626-1638. https://doi.org/10.1016/j. celrep.2015.02.012

117. Kasamatsu A, Uzawa K, Shimada K, Shiiba M, Otsuka Y, Seki N, Abiko Y, Tanzawa H (2005) Elevation of galectin-9 as an inflammatory response in the periodontal ligament cells exposed to Porphylomonas gingivalis lipopolysaccharide in vitro and in vivo. Int J Biochem Cell Biol 37(2):397-408. https://doi.org/ 10.1016/j.biocel.2004.07.014

118. Moore E, Blatt K, Chen A, Van Hook J, DeFranco EA (2016) Relationship of trimester-specific smoking patterns and risk of preterm birth. Am J Obstet Gynecol 215(1):109 e101-109 e106. https://doi.org/10.1016/j.ajog.2016.01.167

119. Crowther CA, Ashwood P, McPhee AJ, Flenady V, Tran T, Dodd JM, Robinson JS, Group PS (2017) Vaginal progesterone pessaries for pregnant women with a previous preterm birth to prevent neonatal respiratory distress syndrome (the PROGRESS Study): a multicentre, randomised, placebo-controlled trial. PLoS Med 14(9):e1002390. https://doi.org/10.1371/journal.pmed.1002390

120. Berghella V, Palacio M, Ness A, Alfirevic Z, Nicolaides KH, Saccone G (2017) Cervical length screening for prevention of preterm birth in singleton pregnancy with threatened preterm labor: systematic review and meta-analysis of randomized controlled trials using individual patient-level data. Ultrasound Obstet Gynecol 49(3):322-329. https://doi.org/10.1002/uog. 17388

121. Melchor JC, Khalil A, Wing D, Schleussner E, Surbek D (2018) Prediction of preterm delivery in symptomatic women using PAMG-1, fetal fibronectin and phIGFBP-1 tests: systematic review and meta-analysis. Ultrasound Obstet Gynecol 52(4):442451. https://doi.org/10.1002/uog.19119

122. Norman JE, Marlow N, Messow CM, Shennan A, Bennett PR, Thornton S, Robson SC, McConnachie A, Petrou S, Sebire NJ, Lavender T, Whyte S, Norrie J, Group OS (2016) Vaginal progesterone prophylaxis for preterm birth (the OPPTIMUM study): a multicentre, randomised, double-blind trial. Lancet (London, England) 387(10033):2106-2116. https://doi.org/10.1016/ S0140-6736(16)00350-0

123. Nicolaides KH, Syngelaki A, Poon LC, Picciarelli G, Tul N, Zamprakou A, Skyfta E, Parra-Cordero M, Palma-Dias R, Rodriguez Calvo J (2016) A randomized trial of a cervical pessary to prevent preterm singleton birth. N Engl J Med 374(11):10441052. https://doi.org/10.1056/NEJMoa1511014

124. Berghella V, Odibo AO, To MS, Rust OA, Althuisius SM (2005) Cerclage for short cervix on ultrasonography: meta-analysis of trials using individual patient-level data. Obstet Gynecol 106(1): 181-189. https://doi.org/10.1097/01.AOG.0000168435.17200.53

125. Roberts D, Brown J, Medley N, Dalziel SR (2017) Antenatal corticosteroids for accelerating fetal lung maturation for women at risk of preterm birth. Cochrane Database Syst Rev 3: CD004454. https://doi.org/10.1002/14651858.CD004454.pub3

126. Tomiie M, Isaka S, Miyoshi E, Taniguchi N, Kimura T, Ogita K, Tsutsui T, Shimoya K, Nakagawa T, Kondo A, Koyama M, Murata Y (2005) Elevated expression of $\mathrm{N}$ acetylglucosaminyltransferase $\mathrm{V}$ in first trimester human placenta. Biochem Biophys Res Commun 330(3):999-1004. https://doi. org/10.1016/j.bbrc.2005.02.186

127. Yamamoto E, Ino K, Miyoshi E, Inamori K, Abe A, Sumigama S, Iwase A, Kajiyama H, Shibata K, Nawa A, Kikkawa F (2009) Nacetylglucosaminyltransferase $\mathrm{V}$ regulates extravillous trophoblast invasion through glycosylation of alpha5beta1 integrin. Endocrinology 150(2):990-999. https://doi.org/10.1210/en.20081005 
128. Ji L, Brkic J, Liu M, Fu G, Peng C, Wang YL (2013) Placental trophoblast cell differentiation: physiological regulation and pathological relevance to preeclampsia. Mol Asp Med 34(5):9811023. https://doi.org/10.1016/j.mam.2012.12.008

129. Jansen BC, Bondt A, Reiding KR, Lonardi E, de Jong CJ, Falck D, Kammeijer GS, Dolhain RJ, Rombouts Y, Wuhrer M (2016) Pregnancy-associated serum N-glycome changes studied by highthroughput MALDI-TOF-MS. Sci Rep 6:23296. https://doi.org/ 10.1038/srep23296

130. Varki A (1993) Biological roles of oligosaccharides: all of the theories are correct. Glycobiology 3(2):97-130. https://doi.org/ 10.1093/glycob/3.2.97

131. Lauc G, Zoldos V (2010) Protein glycosylation-an evolutionary crossroad between genes and environment. Mol BioSyst 6(12): 2373-2379. https://doi.org/10.1039/c0mb00067a

132. Kaszuba K, Grzybek M, Orlowski A, Danne R, Rog T, Simons K, Coskun U, Vattulainen I (2015) N-glycosylation as determinant of epidermal growth factor receptor conformation in membranes. Proc Natl Acad Sci U S A 112(14):4334-4339. https://doi.org/ 10.1073/pnas. 1503262112

133. Acheson A, Sunshine JL, Rutishauser U (1991) NCAM polysialic acid can regulate both cell-cell and cell-substrate interactions. J Cell Biol 114(1):143-153

134. Kolundzic N, Bojić-Trbojević Ž, Kovačević T, Stefanoska I, Kadoya T, Vićovac L (2011) Galectin-1 is part of human trophoblast invasion machinery - a functional study in vitro. PLoS One 6(12):e28514

135. Bojic-Trbojevic Z, Jovanovic Krivokuca M, Stefanoska I, Kolundzic N, Vilotic A, Kadoya T, Vicovac L (2018) Integrin beta1 is bound to galectin-1 in human trophoblast. J Biochem 163(1):39-50. https://doi.org/10.1093/jb/mvx061

136. Moss L, Prakobphol A, Wiedmann TW, Fisher SJ, Damsky CH (1994) Glycosylation of human trophoblast integrins is stage and cell-type specific. Glycobiology 4(5):567-575

137. Liao WC, Liu CH, Chen CH, Hsu WM, Liao YY, Chang HM, Lan CT, Huang MC, Shyu MK (2015) beta-1,4-galactosyltransferase III suppresses extravillous trophoblast invasion through modifying beta1-integrin glycosylation. Placenta 36(4):357-364. https://doi. org/10.1016/j.placenta.2015.01.008

138. Jovanovic M, Stefanoska I, Radojcic L, Vicovac L (2010) Interleukin-8 (CXCL8) stimulates trophoblast cell migration and invasion by increasing levels of matrix metalloproteinase (MMP)2 and MMP9 and integrins alpha5 and beta1. Reproduction 139(4):789-798. https://doi.org/10.1530/REP-090341

139. Li CM, Hou L, Zhang H, Zhang WY (2014) CCL17 induces trophoblast migration and invasion by regulating matrix metalloproteinase and integrin expression in human first-trimester placenta. Reprod Sci. https://doi.org/10.1177/1933719113519170

140. Furmento VA, Marino J, Blank VC, Cayrol MF, Cremaschi GA, Aguilar RC, Roguin LP (2016) Granulocyte colony-stimulating factor (G-CSF) upregulates beta 1 integrin and increases migration of human trophoblast Swan 71 cells via PI3K and MAPK activation. Exp Cell Res 342(2):125-134. https://doi.org/10.1016/j. yexcr.2016.03.005

141. Gleeson LM, Chakraborty C, McKinnon T, Lala PK (2001) Insulin-like growth factor-binding protein 1 stimulates human trophoblast migration by signaling through alpha 5 beta 1 integrin via mitogen-activated protein Kinase pathway. J Clin Endocrinol Metab 86(6):2484-2493. https://doi.org/10.1210/jcem.86.6.7532

142. Zhang M, Wang M, Gao R, Liu X, Chen X, Geng Y, Ding Y, Wang Y, He J (2015) Altered beta1,6-GlcNAc and bisecting GlcNAc-branched N-glycan on integrin beta1 are associated with early spontaneous miscarriage in humans. Hum Reprod 30(9): 2064-2075. https://doi.org/10.1093/humrep/dev153
143. Deng Q, Chen Y, Yin N, Shan N, Luo X, Yuan Y, Liu Y, Liu X, Qi H (2017) The role of MGAT5 in human umbilical vein endothelial cells. Reprod Sci 24(2):313-323. https://doi.org/10.1177/ 1933719116655602

144. Pang PC, Chiu PC, Lee CL, Chang LY, Panico M, Morris HR, Haslam SM, Khoo KH, Clark GF, Yeung WS, Dell A (2011) Human sperm binding is mediated by the sialyl-Lewis(x) oligosaccharide on the zona pellucida. Science 333(6050):1761-1764. https://doi.org/10.1126/science. 1207438

145. Pang PC, Tissot B, Drobnis EZ, Sutovsky P, Morris HR, Clark GF, Dell A (2007) Expression of bisecting type and Lewisx/ Lewisy terminated $\mathrm{N}$-glycans on human sperm. J Biol Chem 282(50):36593-36602. https://doi.org/10.1074/jbc.M705134200

146. Pang PC, Tissot B, Drobnis EZ, Morris HR, Dell A, Clark GF (2009) Analysis of the human seminal plasma glycome reveals the presence of immunomodulatory carbohydrate functional groups. J Proteome Res 8(11):4906-4915. https://doi.org/10.1021/ pr9001756

147. Szczykutowicz J, Kaluza A, Kazmierowska-Niemczuk M, FerensSieczkowska M (2019) The potential role of seminal plasma in the fertilization outcomes. Biomed Res Int 2019:5397804. https://doi. org/10.1155/2019/5397804

148. Tiensuu H, Haapalainen AM, Karjalainen MK, Pasanen A, Huusko JM, Marttila R, Ojaniemi M, Muglia LJ, Hallman M, Ramet M (2019) Risk of spontaneous preterm birth and fetal growth associates with fetal SLIT2. PLoS Genet 15(6): e1008107. https://doi.org/10.1371/journal.pgen.1008107

149. Moore T, Dveksler GS (2014) Pregnancy-specific glycoproteins: complex gene families regulating maternal-fetal interactions. Int $\mathrm{J}$ Dev Biol 58(2-4):273-280. https://doi.org/10.1387/ijdb. 130329gd

150. Arnold LL, Doherty TM, Flor AW, Simon JA, Chou JY, Chan WY, Mansfield BC (1999) Pregnancy-specific glycoprotein gene expression in recurrent aborters: a potential correlation to interleukin-10 expression. Am J Reprod Immunol 41(3):174 182. https://doi.org/10.1111/j.1600-0897.1999.tb00530.x

151. Koistinen R, Heikinheimo M, Rutanen EM, Stenman UH, Lee JN, Seppala M (1981) Concanavalin A binding of pregnancy-specific beta-1-glycoprotein in normal pregnancy and trophoblastic disease. Oncodev Biol Med 2(3):179-182

152. Mendoza M, Lu D, Ballesteros A, Blois SM, Abernathy K, Feng C, Dimitroff CJ, Zmuda J, Panico M, Dell A, Vasta GR, Haslam SM, Dveksler G (2020) Glycan characterization of pregnancyspecific glycoprotein 1 and its identification as a novel galectin-1 ligand. Glycobiology. https://doi.org/10.1093/glycob/cwaa034

153. Schiefner A, Rodewald F, Neumaier I, Skerra A (2015) The dimeric crystal structure of the human fertility lipocalin glycodelin reveals a protein scaffold for the presentation of complex glycans. Biochem J 466(1):95-104. https://doi.org/10.1042/bj20141003

154. Dell A, Morris HR, Easton RL, Panico M, Patankar M, Oehniger S, Koistinen R, Koistinen H, Seppala M, Clark GF (1995) Structural analysis of the oligosaccharides derived from glycodelin, a human glycoprotein with potent immunosuppressive and contraceptive activities. J Biol Chem 270(41):24116-24126. https://doi.org/10.1074/jbc.270.41.24116

155. Lee CL, Pang PC, Yeung WS, Tissot B, Panico M, Lao TT, Chu IK, Lee KF, Chung MK, Lam KK, Koistinen R, Koistinen H, Seppala M, Morris HR, Dell A, Chiu PC (2009) Effects of differential glycosylation of glycodelins on lymphocyte survival. J Biol Chem 284(22):15084-15096. https://doi.org/10.1074/jbc. M807960200

156. Lee CL, Chiu PC, Pang PC, Chu IK, Lee KF, Koistinen R, Koistinen H, Seppala M, Morris HR, Tissot B, Panico M, Dell A, Yeung WS (2011) Glycosylation failure extends to glycoproteins in gestational diabetes mellitus: evidence from reduced alpha2-6 sialylation and impaired immunomodulatory activities 
of pregnancy-related glycodelin-A. Diabetes 60(3):909-917. https://doi.org/10.2337/db10-1186

157. Billionnet C, Mitanchez D, Weill A, Nizard J, Alla F, Hartemann A, Jacqueminet $S$ (2017) Gestational diabetes and adverse perinatal outcomes from 716,152 births in France in 2012. Diabetologia 60(4):636-644. https://doi.org/10.1007/s00125-017-4206-6

158. Bolton AE, Pockley AG, Clough KJ, Mowles EA, Stoker RJ, Westwood OM, Chapman MG (1987) Identification of placental protein 14 as an immunosuppressive factor in human reproduction. Lancet 1(8533):593-595. https://doi.org/10.1016/s01406736(87)90235-2

159. Mukhopadhyay D, Sundereshan S, Rao C, Karande AA (2001) Placental protein 14 induces apoptosis in T cells but not in monocytes. J Biol Chem 276(30):28268-28273. https://doi.org/10. 1074/jbc.M010487200

160. Cappelletti M, Della Bella S, Ferrazzi E, Mavilio D, Divanovic S (2016) Inflammation and preterm birth. J Leukoc Biol 99(1):6778. https://doi.org/10.1189/jlb.3MR0615-272RR

161. Lee J, Kim JS, Park JW, Park CW, Park JS, Jun JK, Yoon BH (2013) Chronic chorioamnionitis is the most common placental lesion in late preterm birth. Placenta 34(8):681-689. https://doi. org/10.1016/j.placenta.2013.04.014

162. Ogge G, Romero R, Lee DC, Gotsch F, Than NG, Lee J, Chaiworapongsa T, Dong Z, Mittal P, Hassan SS, Kim CJ
(2011) Chronic chorioamnionitis displays distinct alterations of the amniotic fluid proteome. J Pathol 223(4):553-565. https:// doi.org/10.1002/path.2825

163. Ibeto L, Antonopoulos A, Grassi P, Pang PC, Panico M, Bobdiwala S, Al-Memar M, Davis P, Davis M, Norman Taylor J, Almeida P, Johnson MR, Harvey R, Bourne T, Seckl M, Clark G, Haslam SM, Dell A (2020) Insights into the hyperglycosylation of human chorionic gonadotropin revealed by glycomics analysis. PLoS One 15(2):e0228507. https://doi. org/10.1371/journal.pone.0228507

164. Akgul Y, Holt R, Mummert M, Word A, Mahendroo M (2012) Dynamic changes in cervical glycosaminoglycan composition during normal pregnancy and preterm birth. Endocrinology 153(7):3493-3503. https://doi.org/10.1210/en.2011-1950

165. Critchfield AS, Yao G, Jaishankar A, Friedlander RS, Lieleg O, Doyle PS, McKinley G, House M, Ribbeck K (2013) Cervical mucus properties stratify risk for preterm birth. PLoS One 8(8): e69528. https://doi.org/10.1371/journal.pone.0069528

Publisher's note Springer Nature remains neutral with regard to jurisdictional claims in published maps and institutional affiliations. 